\title{
RECONOCIMIENTO DE PATERNIDAD. TÓPICOS Y CUESTIONES CIVILES
}

\author{
EDUARDO GANDULFO R.*
}

RESUMEN: En el presente texto se pretende: 1. Brindar una justificación de la figura del reconocimiento. 2. Investigar su ámbito de operatividad en los contextos, los procedimientos de la filiación y los contextos de la misma. 3. Examinar las calificaciones jurídicas más próximas a que puede reconducirse. 4. Analizar las diversas características del reconocimiento. 5. Revisar los sujetos que intervienen en esta relación bilateral y su posición: $5.1 \mathrm{La}$ persona que puede reconocer y 5.2. La persona que puede ser reconocida. 6. Analizar la expresión de voluntad necesaria para reconocer. 7. Examinar las formalidades del acto: 7.1. Las formalidades por vía de solemnidad. a) el reconocimiento por acto inter vivos extrajudicial. b) el reconocimiento por acto mortis causa: el testamento. c) la admisión en vía judicial. 7.2. Las formalidades de publicidad y de prueba. 7.3. Las consecuencias por falta u omisión de formalidades. 8. Ver las formas de dejar sin valor directamente el reconocimiento.

Palabras clave: familia, filiación, determinación de la filiación, reconocimiento de paternidad, factor de determinación, estado civil, paternidad, ius personarum.

ABSTRACT: In the present text it is tried: 1 . To offer a justification of the figure of recognition. 2. To investigate its scope of operation in the contexts of parental recognition procedures and its contexts. 3. To examine the closest legal qualifications that can be led back. 4. To analyze the characteristics of recognition. 5. To review the subjects taking part in this bilateral relation and its position: 5.1 The person who can recognize and 5.2. The person who can be recognized. 6 . To analyze the expression of will necessary to recognize. 7. To examine the formalities of the act: 7.1. The formalities by way of solemnity. a) the recognition by extrajudicial, inter vivos act. c) the recognition by mortis causa act: the testament. b) the admission in the judicial track. 7.2. The prove and publicity formalities. 7.3. The consequences by lack or omission of formalities. 8. To see the forms to leave without value the recognition directly.

Key words: family, filiation, determination of filiation, acknowledgement of paternity, factor of determination, civil status, paternity, ius personarum.

$$
\begin{gathered}
\text { "Cuando yo era un niño } \\
\text { Y todo lo ignoraba } \\
\text { Volvía mis ojos extraviados hacia el sol } \\
\text { Como si en lo alto hubiera } \\
\text { Un oído para escuchar mi queja, } \\
\text { Un corazón como el mio } \\
\text { Que se apiadara del sufriente". } \\
\text { W. GOETHE (Prometheus) }
\end{gathered}
$$

\footnotetext{
* El autor es postgraduado como Especialista en Argumentación Jurídica en la Universitat d'Alacant. Además, agradece las revisiones críticas de don Álvaro Quintanilla P., don Carlos Cerda A. y don Francesco Carretta M.
} 


\section{JUSTIFICACIÓN DE LA FIGURA}

En el ámbito del factor reconocimiento se encuentra uno de los pocos espacios que el derecho de la filiación le dispone a la autonomía de la voluntad. Sabemos que el interés general involucrado en el tema de la filiación ha perfilado toda esta materia, para efectos de lograr una mayor protección del individuo, tanto de su existencia como de su normal desarrollo; además, debe agregarse que la filiación no afecta unilateralmente a un individuo, sino que se trata de una relación bilateral, padre/madre-hijo, por lo que cualquier toma de decisión individual va a afectar e involucrar a otro junto a él (sin contar con la situación general del estado filial). De allí que el ámbito de la autonomía de la voluntad se restrinja a los casos expresamente contemplados por la ley. Sin embargo, cuál es la razón de contemplar esta figura o, de otra manera, cuál es la justificación que pretende concretar esta figura y que determine sus límites. No debe perderse de vista que esta figura del reconocimiento, concebida tal y como está, ha recibido críticas por su "excesivo e injustificado voluntarismo, menos comprensible hoy en un sistema basado fundamentalmente en el principio de veracidad"1, es decir, habría una razón de principios para no contemplarla.

La constitución del vínculo jurídico filial, al estabilizar con la forma jurídica una situación y, a su vez, abrir la puerta a un cierto haz de derechos, obligaciones y deberes filiales (como los alimentos, tuición y visitas), importa, de tal modo, una concreción de mayor protección para los individuos involucrados en esta clase de relaciones, en especial, de quienes pueden ser la parte más débil de la relación, los niños ${ }^{2}$. Por esto, la filiación jurídica es una figura que se entiende que la ley debe favorecer. El contexto fáctico de la justificación estriba en lo siguiente: la operatividad de hecho de los factores que no actúan simplemente ope legis (esto es, los que requieren ir a un proceso jurisdiccional para constituirlos), puede hacer bastante engorroso el acceso a la filiación jurídica. Corrobora lo expuesto, el que la propia ley contemple la posibilidad de configurar una presunción para el padre biológico, que tenga un comportamiento desleal en la oposición del juicio de reclamación (art. 203). Así, aparece como necesario configurar un factor de determinación de la filiación de carácter más simple que los factores jurisdiccionales. Pero ¿por qué el delineo que presenta el acto de reconocimiento?

Si se une a lo previamente expuesto una idea base del Derecho Constitucional, la que se llama "autonomía individual", que se trata de la capacidad de tomar decisiones y adquirir convicciones de forma libre, racional ${ }^{3}$ y responsable que tienen los individuos en general, entonces la ley puede dejar descansar en dicha capacidad individual la toma de decisión de admitir formalmente la progenitura biológica respecto de alguien, sope-

\footnotetext{
${ }^{1}$ Rivero Hernández, (1997) n 280, pp. 487 y 488.

2 Tal conclusión ya se hallaba presente en tiempo antiguo. Así, Homero decía en boca de Pisístrato: "grandes son los pesares de un hijo si el padre le falta de su casa y en ella no hay otro que pueda ampararle. Tal le ocurre a Telémaco: ausente su padre, no tiene en su propio país quien alcance a evitar su ruina”. (2000) libro IV, versos 164 a 167.

${ }^{3} \mathrm{La}$ tesis de la capacidad de actuar en torno a razones, la tomo, en parte, de DAVIDSON (1982) pp. 289 a 305. Una aplicación más o menos similar se puede ver en GANDULFO (2005a) pp. 365 y 366.
} 
sando su experiencia personal de tipo sexual y moral, para producir la activación de la atribución legal de la filiación jurídica, siempre y cuando a quien se pretenda hijo, no tenga esa específica filiación previamente determinada. De nuevo, mirando el contexto fáctico, esta relación es personalísima, por lo que no da lo mismo para las personas, en general, ser padre de Juan que de Diego o Carolina, ya que en esta relación está involucrada algo más que relaciones patrimoniales, sino que hay una relación mucho más vasta $y$, culturalmente, una proyección del padre en el hijo. Y esta relación más compleja tiene su plasmación en ese haz de derechos y deberes filiales que imponen a los padres una fuerte carga para asumir respecto de sus hijos jurídicos. Es por ello que se considera que las personas no van por la vida reconociendo a cualquiera como hijos.

Finalmente, ante tal facilidad para poder construir el acto en estudio y entrar en la filiación, la ley establece contrapesos ex post. En efecto, no es tan simple constituir una relación y quedarse en ella sin más. Se prescribe un mecanismo de relativa facilidad para rechazar una filiación sin un trasfondo biológico real. La acción de impugnación del estado filial contiene un procedimiento de relativa facilidad, a través de las pericias biológicas, para poder acreditar que determinada persona no es padre de otra, disponiendo la ley, a su vez, cálculos de plazos más benévolos a favor del hijo. Y a ello se agrega un derecho a repudiación a favor del hijo, de ejercicio discrecional para él.

Luego de sumar y restar argumentos, creo que el Derecho de la Filiación, bajo tales circunstancias, considera admisibles los casos de participación de la autonomía de la voluntad dirigida hacia una finalidad de orden público, y así le marca los límites del factor reconocimiento.

\section{2. ÁMBITO DE OPERATIVIDAD}

Dentro de las diversas situaciones que la ley tiene en consideración para establecer como criterio-base del procedimiento de constitución de la filiación, podemos encontrar: la apelación al criterio biológico natural, los sucesos sociales, la adopción y la reproducción asistida. El factor reconocimiento encuentra su ámbito de acción dentro del procedimiento de constitución de la filiación por naturaleza. Ello debido a que este factor se basa en una convicción de ser el verdadero progenitor, bajo el supuesto de las relaciones sexuales experimentadas entre los padres biológicos. Asimismo, al revisarse la disposición del articulado del Código Civil, se puede captar que el reconocimiento está tratado a raíz del procedimiento por naturaleza ${ }^{4}$, que viene expresado desde el art. 183 en adelante y, en especial, en el art. 185 inc. 2, y arts. 186 a 190. Es por ello que, en definitiva, este factor constituye una manifestación de la ocurrencia del hecho biológico de la concepción natural, al afirmar que el hijo es suyo, tal y como señala el art. 213: "si el padre hubiese reconocido al hijo como suyo"; aunque mediatizado por las razones que justifican esta figura. Tres consecuencias necesarias de tal postura, serán: $i$.- que el estado

\footnotetext{
${ }^{4}$ Sobre el procedimiento por naturaleza, se refiere al criterio para dar origen a la filiación, llamado por naturaleza que se encuentra dentro de la clase de los procedimientos para dar origen al estado filial. Ver necesariamente mi texto base sobre la filiación, en donde presento una nueva ordenación: GANDULFO (2006) pp. 55 a 57 y 51 a 54.
} 
jurídico que opera en base a este acto lo hace de forma retroactiva (art. 189 inc. 3); ii.que no hay límite moral para el reconocimiento, por lo que se puede reconocer a un hijo producto de un incesto, y iii.- que el único límite será el biológico natural.

Otra consecuencia es que el reconocimiento no opera dentro los procedimientos regidos bajo la égida de otro criterio-base para dar origen a la filiación. Por ejemplo, no puede operar bajo el régimen del criterio-base "adopción", puesto que este, como los otros, contiene procedimientos más adecuados a las características propias del criterio base de que se trate.

Tanto en el Derecho chileno como en el español, el reconocimiento es perfilado por el ordenamiento jurídico como una figura de Derecho común dentro de la filiación, aplicándose no solo a la filiación en contexto no matrimonial, sino también en algunas situaciones matrimoniales 5 .

Así, uno de los supuestos más típicos de aplicación del reconocimiento a circunstancias fácticas de orden matrimonial, es el matrimonio de los padres sobrevenido al nacimiento. De ello da cuenta el art. 185 inc. 1 al enunciar: "Tratándose del hijo nacido antes de casarse sus padres, la filiación matrimonial queda determinada por la celebración de ese matrimonio, siempre que la maternidad y la paternidad estén ya determinadas con arreglo al artículo 186 o en caso contrario, por el último reconocimiento conforme a lo establecido en el párrafo siguiente”.

Sin embargo, cabe la pregunta de si el reconocimiento es viable también en supuestos de situación matrimonial originaria. Creo que sí se puede en un cierto sentido. Si se hallase un caso que deba recibir dicha aplicación, aunque sea de difícil ocurrencia, debe agregarse en el elenco de situaciones de una determinada figura, puesto que constituye el contracaso para una teoría opuesta, contribuye a la perfección técnica de la institución y, principalmente, permite que si se da el caso particular, pueda recibir adecuada repuesta ${ }^{6}$; el caso ya lo he expuesto en otro texto, y aquí lo resumiré de la siguiente manera:

Puede ocurrir que en un matrimonio, el marido, Ramón Cabello, abandona a su mujer, Josefina Rojas, estando embarazada. Ella tiene su bebé en casa o en las afueras, llamada Blanca, y la abandona, p. ej., en la calle o en una acequia -como hemos leído más de una vez-. Blanca está sin filiación respecto de ambos padres biológicos y queda en una casa de expósito. Pasa el tiempo y el verdadero padre, Ramón Cabello, se entera de la situación, encuentra a Blanca y la reconoce. Con ello, Blanca queda con su filiación paterna determinada. Posteriormente, R. Cabello demanda de reclamación de estado a su mujer, y la sentencia decreta la filiación materna de Josefina para con Blanca. En virtud de la operatividad excluyente de los factores y estando ya constituida la filiación paterna por acto de admisión, entonces el factor reconocimiento predominará sobre el factor 'nacimiento dentro del matrimonio...' del art. 184, obliterando su operatividad ${ }^{7}$. Así, Blanca nació en una situación matrimonial originaria de ambos padres, pero su filiación tuvo como origen el factor reconocimiento.

\footnotetext{
${ }^{5}$ Rivero HernÁNDEZ (1997) n 280, p. 287.

${ }^{6}$ Para la selección de las hipótesis hermenéuticas sobre la ley, GANDULFO (2002) pp. 485 a 532.

7 GANDUlFo (2006) p. 45.
} 
Como se ve, con este contra-caso se refuta la hipótesis absoluta de que el reconocimiento no tiene, técnicamente hablando, funcionamiento en esta clase de situaciones matrimoniales originarias, porque existen casos en que pueden caer bajo los supuestos de reconocimiento.

\section{CALIFICACIÓN JURÍDICA}

\subsection{SE TRATA DE UN FACTOR DE DETERMINACIÓN DE LA FILIACIÓN}

3.1.1. En primer término, si este tema se encuentra inserto dentro del tema de los factores de la filiación, entonces esta figura lo será del procedimiento de constitución y es allí donde el reconocimiento encontrará su ámbito de operatividad, y no en el estado filial mismo, ni menos en el haz de derechos y obligaciones atribuidos a la filiación ${ }^{8}$. Por lo tanto, el acto de reconocimiento no consiste en ser el estado filial mismo, sino solo una vía para constituirlo.

En segundo término, entrando al tema, el reconocimiento es un factor de determinación y no al revés, ni son lo mismo desde un punto de vista lógico. El que sea un factor significa que es una de las manifestaciones externas de un criterio-base seleccionado por la ley para efectos de permitir la operación de constitución del estado filial ${ }^{9}$; en nuestra clase de caso, su atribución o determinación legal.

Algunos han confundido la calidad de ser miembro, el "reconocimiento", con lo que es su clase el "factor de determinación de la filiación". P. ej., la Corte de Apelaciones de Concepción -en uno de sus primeros fallos sobre la reforma filial- consideró que la sentencia es una especie de reconocimiento, en particular, forzado, mientras que el acto de reconocimiento mismo sería un reconocimiento voluntario ${ }^{10}$. Aunque más grave es la falta de distinción de la abogada del SERNAM, Carolina Espinoza, quien, desconociendo el nuevo sistema de la reforma a la filiación, manifestó que la sentencia constitutiva de estado filial es una "sentencia de reconocimiento" -más propio de una calificación en el viejo orden filial ${ }^{11}$.

Esta categorización es absolutamente inadecuada en el nuevo derecho de la filiación. Tal tipo de afirmación posee "confusiones en la relación de 'clase' y 'miembro', e introduce algunas categorías de la antigua ley filial". La resolución de la Corte de Concepción, p. ej., "mantiene las categorías de reconocimiento forzado y voluntario, para referirse a los factores de determinación que son: la norma sentencial y el acto de reconocimiento. La nueva ley establece como clase la categoría de factor de determinación", y como miembros de ella: "los factores particulares, como la sentencia, el parto, el reconocimiento, etc. Por tanto, no todo factor de determinación es reconocimiento, y posee una identidad distinta la sentencia jurisdiccional, la cual no reconoce al menor como hijo de alguien, sino que derechamente lo constituye de forma jurídica, como hijo

\footnotetext{
${ }^{8}$ GANDULFO (2006) pp. 51 a 54.

${ }^{9}$ GANDULFO (2006) pp. 73 y 74.

${ }^{10} R D J$., tomo 98 (2001), II, sección $2^{\text {a }}$, pp. 39 y ss.

11 Opinión manifestada en la Comisión Mixta para el estudio de la Ley 20.030. Informe de Comisión Mixta. Boletín 3.043-07.
} 
de tal persona. Ello claramente puede verse por dos cosas: cuando se entiende que el reconocimiento es un acto, privado, de admisión, y la sentencia es un acto jurisdiccional de orden constitutivo; y, por otra, en la tajante separación que efectúa la ley entre sentencia y reconocimiento: en el art. 186 indica que 'la filiación... queda determinada legalmente por reconocimiento del padre, la madre... o por sentencia firme en juicio de filiación' y, consecuentemente, al regular el reconocimiento, en el Tít. VII párr. 4, arts. 186 y ss., mientras que la sentencia firme está regulada en el Tít. VIII parrs. 2 y 3, arts. 204 y ss. Cuando la nueva ley civil habla de "reconocimiento", ya supone e incluye que este es voluntario, y así lo dice la ley: 'El reconocimiento del hijo tendrá lugar mediante declaración formulada con ese determinado objeto por el padre, la madre o ambos', por lo que es trivial calificarlo voluntario en este contexto" 12 .

Por tanto, debe entenderse que el reconocimiento es un miembro más dentro de la clase de los factores de determinación y que, así, todo reconocimiento es factor, pero no todo factor es reconocimiento. En tal sentido, este acto constituye un factor de tipo no normativo y extrajurisdiccional ${ }^{13}$.

3.1.2. Debe descartarse que este acto se trate de un "medio de prueba", en especial de un acto de confesión, a pesar de que la legislación señalaba en el ex inc. 2 del art. 188 que, "también lo es [reconocimiento] la confesión de paternidad o maternidad...".

Primero, tal enunciación fue derogada, por lo que tal calificación ya no tiene apoyo en los enunciados legaliformes.

Segundo, Manuel Peña Bernaldo de Quirós dice que el autor del reconocimiento solo puede tener razones (o evidencia) de la posibilidad de ser él el padre, pero no la realidad de ello. V.gr., del hecho personal de haber tenido relaciones sexuales en tiempo adecuado para producir la determinada concepción con una precisa mujer. Para la mujer reconociente tampoco es una exigencia, pues es posible, v.gr., que esta hubiese abandonado a su hijo a tempranísima edad, antes de la inscripción inclusive, y solo tenga evidencia por dichos de parientes o amigos. Así, la admisión de la paternidad no es un hecho personal del "confesante", como para poder confesarlo ${ }^{14}$.

Pero ello no es tan así, pues aquí falta la conexión con el criterio base, que es el biológico natural. Por ende, la realidad de ello, se refiere a tener evidencia de la relación biológica de padre e hijo. Se puede contar con tal evidencia mediante los exámenes de ADN; de tal manera que es falsa la afirmación de Peña. Lo que sucede es que, como señalé, la finalidad de la figura legal del reconocimiento es facilitar la constitución de la relación jurídica filial. En consecuencia, la construcción legal del acto no exige tener evidencia cierta de la relación biológica, pues en tal caso siempre requeriría estar fundada en exámenes biológicos más o menos precisos, como los de ADN. La figura típica del acto de reconocimiento solo supone y considera tener evidencia respecto de hechos conexos con la procreación, que le permiten al sujeto estimar una posibilidad de ser el padre o

\footnotetext{
12 Gandulfo (2006) p. 88, n. 92.

13 GANDULFO (2006) pp. 84 y 85.

${ }^{14}$ PENÁ (1989) pp. 427 y 428.
} 
madre. Por ello, si alguien dentro del proceso de filiación es citado a prestar declaración de parte (por el art. 50 LTF.), se le está suponiendo un determinado conocimiento, que no es el mismo que objetivamente supone la figura del reconocimiento, por lo que sus consecuencias, estructura y exigencias son diferentes.

Tercero, tampoco sería confesión, pues, técnicamente, al decir de G. Chiovenda y E. Liebman, esta es "relevadora de la prueba" en el punto declarado, y limita las facultades decisorias del juez dirigiéndolas en una sola dirección fáctica. Trátese más bien de un medio con valor de "prueba legal" o "plena prueba"15. Muy diferente es el régimen del reconocimiento, en que frente a la declaración de admisión no determina la resolución del juez, sino que, por el contrario, el acto la excluye y se constituye el estado filial derechamente.

Cuarto, por lo demás, en la específica configuración del proceso filial -tanto en la primera como la segunda reforma a la filiación- la confesión se encuentra excluida, y la declaración de parte solo estaba y está configurada como mera "declaración de parte". En efecto, por la intervención del orden público, en relación con el principio de verdad biológica, se exigía y se exige respecto de la "declaración de parte" que sea real tal relación biológica. Debe, entonces, complementarse con otros medios de contrastación, por lo que no basta tal "declaración de paternidad". Es más, es posible que se establezca en definitiva una decisión en dirección contraria a la "declaración de parte", en vista del resultado del resto de los medios de contrastación de las pretensiones, en particular, la peritación por $\mathrm{ADN}^{16}$. Es decir, no vale como el acto típico de reconocimiento de paternidad -al cual la ley le atribuye directamente la filiación- y el proceso sigue su curso legal hasta la sentencia definitiva.

Quinto, la confesión tiene un fuerte carácter de acto de conocimiento. La confesión no es un mero acto dispositivo, aunque pueda conducir a ello en ciertos casos. Como dice Liebman, la voluntad presente allí es para querer declarar, pero no necesariamente del contenido; aun así expresa un determinado conocimiento, pues el declarante depone como testigo privilegiado ${ }^{17}$. A diferencia del acto de reconocimiento, en el cual el reconociente dirige su voluntad a la creación del estado de hijo mediante la atribución de ley.

Sexto, el nuevo derecho de la filiación contiene una distinción entre los medios de prueba y los factores de determinación. Ya vimos que los factores de determinación son los necesarios para que opere la atribución o determinación del estado: el parto, la situación del pater is est, el reconocimiento, la sentencia jurisdiccional, v.gr., art. 186. En cambio, los medios de prueba buscan corroborar un hecho para que el juez decida; es decir, para que pueda operar otro factor de determinación: la sentencia; así se puede corroborar en los arts. 189 a $201^{18}$.

15 Chiovenda (1925) pp. 291 y 293; Liebman (1980) pp. 340, 344 y 345.

${ }^{16}$ GANDUlFo (2006) pp. 39 y 40; y Liebman (1946) pp. 26, 34, 35, 46 y 230 y ss.

17 LieBMAN (1980) p. 342.

${ }^{18}$ GANDUlfo (2006) pp. 75 y 76; vid. también CORRAL (1999) p. 43. 


\subsection{SE TRATA DE UN ACTO JURÍDICO, DE ADMISIÓN}

3.2.1. El reconocimiento no consiste en un negocio jurídico o normativo, en cuanto que aquel sea una norma jurídica privada que regule directamente la situación, constituyendo la relación jurídica de la particular filiación y estableciendo las consecuencias jurídicas, como sí lo haría un negocio normativo. La ratio iuris estriba en las restricciones del orden público sobre la filiación y el control que la ley ejerce en este campo, en donde se dejan espacios taxativos y precisos a la autonomía de voluntad. El ciudadano tiene libertad para tomar o no la vía del acto, pero el control sobre la determinación del estado civil lo tiene la ley (lo que se manifiesta también en el tipo cerrado de las formas): las consecuencias jurídicas las atribuye directamente la Ley y no las crea la declaración (el estado filial y el haz de derecho y deberes). De esta manera, nuestra figura se trata más bien de un acto jurídico, por tanto, sin caracteres propiamente normativos (de ahí su cariz de factor no normativo): "La filiación... queda determinada legalmente por el reconocimiento" (art. 186). El acto tan solo declara acerca de un hecho natural y así se precisará la calificación del acto, dirigiendo necesariamente su voluntad a configurarlo de cierta manera específica - permitida por la ley- y no de otra. De ahí que, como dice F. Rivero Hernández, "quien reconoce en la forma y con las condiciones legales es porque quiere que se produzcan los efectos legales correspondientes a la relación paterno-filial"19.

3.2.2. Como acto jurídico se requiere de una declaración de voluntad que esté orientada a provocar el desencadenamiento de la consecuencia jurídica prevista por la ley, de tener formalmente a cierta persona como hijo propio: el estado filial. Desde el punto de vista lógico, se puede decir que la voluntad orientada a tal desencadenamiento, es condición necesaria para la producción del resultado constitutivo del vínculo jurídico filial $^{20}$. Si se miran las cosas desde el ángulo negativo, podemos ver que no se trata de una mera mención a la pasada, dirigida a otro destino, es decir, a propósito de la realización de un negocio o acto diverso, v.gr., un mandato.

Asimismo, el reconocimiento está sometido al régimen de las declaraciones de voluntad de los actos jurídicos, en cuanto a los vicios de la voluntad (art. 202), enfocados desde la perspectiva de la configuración típica de este acto, incluso para el caso de consignación del nombre del padre en la partida de nacimiento.

3.2.3. En cuanto al carácter de acto de admisión, M. Peña señala que tiene tal carácter, pues el Derecho valora solo la voluntad de reconocer, esto es, la decisión de

\footnotetext{
19 Rivero HernándeZ (1997) n² 287, p. 501.

${ }^{20}$ Aguiló (2000) cap. III, $\mathrm{n}^{\circ} 2.3$, apunta a una ilustrativa relación entre acto jurídico y el análisis de los enunciados jurídicos que confieren poderes: "Los actos jurídicos presuponen una regla que confiere poderes, esto es, una regla que indica que si cierto sujeto realiza ciertas acciones, entonces consigue producir cierto resultado institucional". Y agrega: "Desde una perspectiva estructural, las reglas que confieren poderes ligan la producción de un resultado institucional... a la existencia de un determinado estado de cosas conjuntamente con la realización por parte de un sujeto de una o varias acciones orientadas a la producción de dicho resultado.
} 
admitir la propia paternidad ${ }^{21}$. Como enuncia la ley: "si el padre hubiere reconocido al hijo como suyo..." (inc. 2 art. 213). De tal suerte, se ha llegado a decir que el reconocimiento del capaz es puramente "voluntarista", desligándolo de la acreditación de la relación biológica que se admite. Esto tiene un fundamento bien específico, ya señalado más arriba. Con el objetivo de facilitar la constitución de la filiación y, a su vez, de mantenerla firme, el Legislador prescindió de contemplar el supuesto de que el reconociente tuviese medios directos que acrediten su relación biológico-filial. De ahí que, si bien es cierto que él o ella tiene la creencia de que es el padre o madre del reconocido, ello puede que en verdad no sea así, pues puede no tener medios que le den una mayor seguridad de su progenitura. Por tanto, la ley valorará esa creencia de manera fundamental, mas no la realidad de la progenitura. Y ello marca el límite de las impugnaciones, que se restringen -en cuanto al elemento subjetivo del acto- a los fundamentos de la creencia, es decir, a los medios con que contaba para suponer que era verdadera su creencia. Y el examen de ellos se hará insisto- no en vistas a dicha realidad, sino a la realidad de que existan tales medios de contrastación de su creencia.

Desde el punto de vista negativo, se despliegan una serie de consecuencias. La posición voluntarista hace que la verdad de la declaración no sea un elemento de relevancia jurídica en la materia de reconocimiento. En especial, mira a la cuestión de privarlo de valor directamente; así excluye un subtipo de errores impugnadores, en general admisibles, que se basen en el argumento de que sería un error que el reconociente sea padre. Esta dirección especial de la voluntad a realizar un acto de admisión y a desencadenar la atribución del estado filial, la hace incompatible con la idea de que el reconocimiento pueda ser una mera declaración de ciencia o de conocimiento ${ }^{22}$.

No es trascendente si el pretendido padre tiene o no la intención de atribuir al hijo el haz de derechos, obligaciones y deberes dispuestos en la ley -llamados ius personarum- ${ }^{23}$. Incluso, las cláusulas limitativas o modales carecen de cualquier consecuencia jurídica modificatoria.

Por otra parte, dado que la voluntad relevante para el Derecho es la manifestada, no hay reconocimiento sin la declaración de voluntad (legalmente). En su virtud, no puede el juez (en este contexto) sobreponerse al pretendido padre, para superponer su voluntad mediante resolución judicial a la de este, ante su ausencia o negativa de admitir.

Finalmente, el centro voluntarista es una de las razones por las cuales todo reconocimiento es voluntario, y que el legislador suprimió la categoría del forzado. Y ello

21 PeÑA (1989) p. 428.

${ }^{22}$ En esta última, no es condición necesaria dicha dirección de voluntad, pues en su tipificación solo es necesaria la voluntad de realizar un acto de informar -la declaración- y no más. Vid. Ross (1974) pp. 169 y ss., quien señala que en los actos ejecutivos o realizativos -como el reconocimiento- también se realiza un acto de informar; y la parte final de Austin (2006).

${ }^{23}$ DíeZ-PiCAZO y GulLón (1992) p. 260.

Para el ius personarum en relación con el status civil, en un contexto normativista, vid. GANDULFO (2006) pp. 52 y 53, y en la historia del Ius Commune, COING (1996) p. 221: "El status de un hombre determinaba, pues, su situación jurídica personal", de tal manera que -citando a Donellus y VINNIUS- "el ius personarum es, por consiguiente, su consecuencia; aquél [el status] es causa, este effectus". En el mismo sentido, y de manera tajante, se puede ver Planiol y RIPERT (1927) nos 15, 16 y 20, pp. 10, 11, 14 y 15. 
tiene como consecuencia: la sola aceptación de la expresión directa de voluntad para constituir este acto.

\section{CARACTERÍSTICAS}

4.1. Se trata de un acto unilateral. La unilateralidad del reconocimiento se concreta en la participación relevante para dejar perfecto el acto, solo de quien emite la declaración. Además, la constitución del estado filial se erige desde que queda solemnemente perfecta la declaración; de esta manera, se debe entender que el acto es subjetivamente simple ${ }^{24}$. Por ello es que puede hacerse de forma separada por cada uno de los padres. La razón estriba en que, dado que se trata de una admisión de la propia progenitura, ella no guarda -en tanto que admisión- ninguna conexión con la declaración de un tercero en principio. De allí que el art. 186 expresamente contemple de forma separada a los padres declarantes de reconocimiento, al prescribir que "la filiación... queda determinada legalmente por el reconocimiento del padre o de la madre o ambos".

También de allí es que la ley refuerce tal idea, permitiendo al declarante no indicar al otro progenitor. El art. 187 inc. 2 dispone: "Si es uno solo de los padres el que reconoce, no será obligado a expresar la persona en quien o con quien tuvo al hijo" (art. 186 y art. 187 inc. 2). Solo una excepción tiene esta norma, que es la situación del padre que reconoce a un concebido no nacido aún, según se verá.

En el caso contrario, esto es, en el evento de que el reconociente mencione el nombre del otro padre, con quien habría tenido al hijo, según una vieja doctrina, no le hace perder valor al reconocimiento prima facie ${ }^{25}$. Sin embargo, en razón del principio de racionalidad del reconocimiento, si el reconociente, no obstante no tener el deber de individualizar al otro, aun así lo hace y no respecto del padre jurídicamente ya constituido, entonces tal acto no puede tener valor, pues, por un lado, esta no es la vía de indicar quién podría ser el verdadero padre, y, por otro, bajo la égida del criterio-base biológico, deben ambos padres ser correspondientes. De ahí que el oficial del Registro Civil no debe permitir la inscripción, ni en un reclamo el juez deba ordenar al Registro inscribir. $\mathrm{Y}$ a ese reconociente le quedará realizar un nuevo reconocimiento, con la corrección de la imperfección del otro acto, sea consignando correctamente el nombre del otro padre o bien no haciéndolo figurar.

Cuando ambos padres reconocen a un tiempo al hijo y en el mismo documento -como una escritura pública-, lo que hay allí es solo un encuentro coincidente de dos voluntades separadas, dirigidas cada una a reconocer por sí, a alguien como hijo, ya que

${ }^{24}$ Domínguez ÁGUila (1977) pp. 20 a 23, sobre la oposición entre actos unilaterales subjetivamente simples y subjetivamente complejos.

25 Tal orientación fue dictada por una antigua sentencia de la Corte de Apelaciones de Concepción del año 1927, redactada por el juez Humberto Bianchi, en el caso "Santibáñez con Campos", sobre petición de herencia: "8 Que, por lo demás, el padre que reconoce hijos..., no está obligado a expresar el nombre de la persona en quien los hubo y si designa alguna, como lo hizo Sepúlveda en la escritura de 1873, tal declaración no puede afectar a la pretendida madre que no interviene en el acto, y, por lo tanto, no tiene tampoco valor respecto de los hijos". Gaceta de los Tribunales (1927), 20 sem., pp. 772 a 778. También así ABELIUK (2000) p. 72. 
cada uno realiza su acto individual de admisión. La situación de reconocer la paternidad depende de circunstancias personales del reconociente, por lo que no requiere técnicamente de la concurrencia de otra voluntad para formar la voluntad de admisión; situación diferente es que requiera de cierta información. De tal manera que se ve imposible la idea de formar un consentimiento de admitir (salvo expresa adecuación legal). Por consiguiente, la valoración legal del reconocimiento de un padre o madre, no depende del valor jurídico de la declaración del otro. Con una visión analítica estricta, se debe decir que allí hay dos actos individuales en un mismo documento. En la misma situación, si se llega a anular el reconocimiento de un padre por problemas particulares de aquel, no invalidará el acto conjunto del otro reconociente. Así, p. ej., si el reconocimiento del padre, Thomas Aleste, que consta en una acta extendida ante oficial de Registro Civil, y otorgada en conjunción con la madre, Cecilia Jolz, fue anulado porque hubo inducción dolosa de la madre para que reconociera a su hijo Renato, entonces la nulidad del reconocimiento hecho por Thomas Aleste no afectará el acto de Cecilia Jolz, quedando Renato con un solo padre determinado, y, consecuentemente, el Registro Civil no podrá proceder a cancelar las dos inscripciones.

4.1.1. H. Corral sostiene que esta clasificación debe especificarse aún más, señalando que el reconocimiento es un acto unilateral de la subclase de los recepticios, porque aquel puede ser aceptado o repudiado. Sin perjuicio de que no requiera aceptación expresa, Corral estima que, puesto que la ley otorga el derecho al repudio, la aceptación sigue siendo requerida, solo que se presume esta por la falta de repudiación ${ }^{26}$.

A mi juicio no es correcta tal tesis, tanto porque el reconocimiento no es un acto recepticio, como porque no presenta una verdadera descripción de lo que sea un acto recepticio:

$1^{\circ} \mathrm{El}$ acto recepticio técnicamente no requiere para su perfeccionamiento de aceptación o repudiación, sino su mera emisión; mientras que para que se atribuyan las consecuencias: comunicación. Así, debe recordarse que el criterio por el cual se construye la idea del acto o negocio unilateral recepticio, está en brindar una seguridad a quienes pueden verse afectados directamente por un acto o negocio unilateral ${ }^{27}$. Es por ello que esta figura gira en torno a la idea de ser un acto efectuado frente a otro. Sin embargo, y sin perder de vista el carácter unilateral del acto, la antedicha protección se concreta en esta clase de actos, en que para que se produzcan las consecuencias jurídicas es necesario que la declaración deba ser comunicada a ese otro que será afectado por el acto o negocio ${ }^{28}$; la atribución de consecuencias es independiente de la posición subjetiva del

${ }^{26}$ CORRAL (1999) p. 56 y n. 24.

27 Así, Flume (1998) pp. 178 y 179. Sin embargo, Flume considera que los actos que van dirigidos a persona indeterminada, deben realizarse frente a una autoridad; lo cual no es considerado por todos.

${ }^{28}$ VON TUHR (1934) párr. 21, p. 123, señala: "La mayoría de las declaraciones de voluntad, sobre todo las que se dan en el campo de las obligaciones, han de dirigirse, para surtir efectos, a una determinada persona. Las declaraciones de voluntad en que se da esta característica suelen englobarse bajo el nombre -poco elegante y exacto por cierto, pero aclimatado ya en el lenguaje técnico-, de 'declaraciones recepticias'... es evidente que lo son, puesto que trascienden a la órbita jurídica de otra persona, siendo necesario, por tanto, que lleguen a conocimiento de ella; para lo cual, lo menos que puede exigirse es que se le dirijan". 
comunicado $^{29}$. Por tanto, exigir aceptación para que el reconocimiento quede perfecto es ir más allá de la propia configuración de los actos recepticios ${ }^{30}$.

$2^{\circ} \mathrm{El}$ acto de reconocimiento no requiere notificación para su perfección actualmente. Con la reforma de la Ley 10.271 se eliminó la actividad de la notificación y aceptación para el perfeccionamiento, y se la reemplazó por la disposición del derecho a repudiar ${ }^{31}$. Esta reforma marca una diferencia profunda con el régimen español, que en el art. 123 CC.esp. dispone que el reconocimiento de un hijo mayor solo produce "efectos" cuando ha sido aceptado, o del art. 124 CC.esp. para el menor o el incapaz, mientras que el art. 126 del mismo cuerpo, dispone lo mismo para el reconocido ya fallecido con respecto de sus herederos ${ }^{32}$.

$3^{\circ}$ Es inadmisible para la certeza jurídica y para la protección que la filiación supone el que, en general, tanto el perfeccionamiento de todo acto de admisión (no significa firmeza a todo evento) como la atribución del estado, queden en suspenso de la aceptación por años (art. 191 inc. 1: "Si fuere menor, nadie podrá repudiarlo sino él [hijo] y dentro de un año, a contar desde que, llegado a la mayor edad supo del reconocimiento"). Así, la tesis recepticia lleva al siguiente absurdo, en relación con la ratio legis de la figura: p. ej., si un padre responsable, Fernan Véliz, opta por el sistema rápido del reconocimiento de su hijita Danielle, recién nacida, para darle así una mayor protección, no logra el efecto querido, sino que deberá esperar por lo menos 18 años para recién constituir el estado filial, a lo menos, porque luego empieza a correr el plazo de un año para repudiar, y todo ello si es que pudo su hija Danielle saber de su reconocimiento; es decir, dicha posición logra hacer exactamente lo contrario de la finalidad de esta figura: promueve la incerteza, y convierte al reconocimiento en un factor poco expedito, cuando no, inútil en ciertas ocasiones.

$4^{\circ}$ Pero, además, dicha tesis provoca una gran discriminación respecto de los hijos nacidos en un contexto no matrimonial, ya que los somete a un régimen procedimental bastante más difícil que el de los que están en un contexto matrimonial, impidiéndoles así acceder al estado de hijo por una gran cantidad de tiempo, por combinación del art. 191 inc. 1 y de la figura de la falta de repudio.

$5^{\circ} \mathrm{La}$ tesis del reconocimiento recepticio necesita crear una presunción de aceptación que no contiene la ley, recurriendo así a una hipótesis ad hoc para intentar salvar la explicación normativa. Porque en materia de aceptación, la ley solo prescribe la expresa

\footnotetext{
29 Galgano (1992) pp. 224 a 226.

30 Veloso (2001) pp. 112 y 113, a pesar de coincidir en que no es un acto recepticio, llega a tal conclusión por medio de una inferencia errada al suponer -igual que Corral- que el acto recepticio requiere aceptación, lo que hace inaceptable su razonamiento.

31 SOMARriva (1955) p. 111 -comisionado en el proyecto de reforma de la Ley 10.271- señalaba que el Legislador tuvo en cuenta los problemas del antiguo sistema, orden a que en "el hecho eran muchos los casos de los padres que se contentaban con otorgar el instrumento público de legitimación [reconocimiento], y por ignorancia o por lo engorroso que era la notificación y aceptación, sobre todo tratándose de hijos menores donde además había que designar un curador, no cumplían con estas exigencias dejando así en la incertidumbre el estado civil del hijo".

32 El Código Civil argentino, por su parte, expresamente dice en su art. 249 que no requiere aceptación del hijo el reconocimiento.
} 
y la tácita según el art. 192, dentro de las cuales no cabe la ausencia de manifestación de voluntad de repudiar. Asimismo, esa tesis termina superponiendo dos figuras para una misma situación: la de caducidad del plazo para repudiar, con la creación de la presunción de aceptación, sin que exista un criterio de identidad que separe una de la otra. Con tal razonamiento, entonces, se deja abierta la puerta para crear cualquier tipo de figura doctrinal sobre otra figura ya aceptada, para justificar cualquier teoría; lo que invalida esta estrategia de crear una presunción doctrinalmente.

$6^{\circ}$ Inclusive, en la legislación modelo de la sección de la filiación del Código Civil, se entiende que el reconocimiento no es un acto recepticio ${ }^{33}$.

Por lo tanto, el reconocimiento es un acto unilateral de corte individual simplemente. De allí que el acto quede perfecto con la emisión solemne de su decisión de admitir la paternidad.

4.1.2. Otrosí, en virtud del carácter unilateral nuestra figura no sería susceptible del acto de reconocimiento simulado. En efecto, Eduardo Niño sostiene que la simulación tiene como un elemento indispensable para la formación del mismo al acuerdo simulatorio ${ }^{34}$. Este consiste, por un lado, en lo que las partes pretenden mostrar con la forma jurídica y, por otro, en la real situación jurídica que los regirá entre ellos respecto de la materia que se expresará formalmente. Siendo así las cosas, no hay cómo realizar jurídicamente el acuerdo de voluntades, en la simulación absoluta y la relativa, de un acto cuya tipicidad de actuación es unilateral no recepticia. Si concurriesen de hecho dos voluntades para formar un consentimiento de admisión, entonces se desconfiguraría por ese solo hecho el acto de reconocimiento. En la clase de actos a la que pertenece el factor reconocimiento, solo es posible realizar la reserva mental, la cual por razón de certeza y seguridad jurídica - relativas a que en el tráfico los individuos tienden a formarse la expectativa siguiendo a la manifestación externa del Derecho ${ }^{35}$ - se oblitera, absolutamente, su viabilidad jurídica.

4.2. No es personalísimo, pero tiene una tendencia a serlo. Si se estipula que el acto personalísimo solo puede realizarlo determinada persona (el padre o la madre), entonces el reconocimiento, al poder realizarse por mandatario, no satisface tal estipulación ${ }^{36}$, por la posibilidad de realizarlo un diputado, de acuerdo al art. 190. No obstante, el régimen jurídico dispuesto por el Código Civil tiene una marcada tendencia ha configurar esta figura como un acto personalísimo, por lo que su realización y la interpretación del régimen deben seguir tal línea (incluso en el reconocimiento en vía judicial está excluido el mandatario). De ahí que, en principio, solo puede realizar el acto el directamente involucrado: "el reconocimiento del hijo tendrá lugar mediante declaración formulada...

\footnotetext{
33 RiVERO HERNÁNDEZ (1997) n² 280, p. 490.

34 NiÑO (1991/1992) p. 81.

35 KRAWIETZ (1988) pp. 253 a 274.

36 Méndez Costa (1984) p. 71, en Argentina. En contra, entre nosotros Fueyo (1959) pp. 450 y 451. En España es absolutamente personalísimo: PEÑA (1989) pp. 429 y 430, DíEZ-PiCAZO y GULLÓN (1992) p. 260 y RIVERO (1997) no 280, p. 490.
} 
por el padre o la madre o ambos" (art. 187), y solo a estricto título legal se permite la excepción.

Dado que la convicción de paternidad y la decisión de reconocerla implica un grave y fuerte compromiso que afecta la identidad y desarrollo del declarante como padre o madre, así como las cargas patrimoniales del mismo, en principio solo se permite que quien tenga esa convicción sea el que reconozca y no otro. La especial relación de filiación no puede dejarse al libre arbitrio de la voluntad de terceros. De tal modo, la regla general es que se trata de un acto que solo podría realizar el reconociente, en virtud de estar inserto en el contexto de la filiación.

A título de excepción, la ley, en el art. 190, expresamente autoriza que solo pueda hacerse vía mandatario, en sede extrajudicial, mediando ciertos requisitos o formalidades que logren satisfacer la justificación de la opción del reconocimiento. De acuerdo con lo anterior, la admisión vía mandato solo puede realizarse por acto inter vivos, mas no mortis causa, por dos razones: primero porque la facultad de testar es indelegable, por orden del art. 1004. Y, en segundo, al estar contenido el encargo en un negocio mortis causa y no ser un acto de mera constatación, entonces la encomienda no tiene vigencia de tal sino con la muerte. De ahí que solo se pueda perfeccionar con la muerte del mandatario, pero al acaecer esta, entonces el contrato de mandato se extinguirá por la muerte del mandante (art. 2163 no 5). Por ello, el art. 190 solo enuncia que: "El reconocimiento por acto entre vivos... podrá realizarse por medio de mandatario".

La ley exige que el mandato se haga: a) por un instrumento auténtico consistente en escritura pública, y $b$ ) que esté facultado especialmente para reconocer a determinada persona como hijo; todo de acuerdo con el art. 190. De esto se puede ver que, de plano, se excluyen los mandatos o poderes generales, por los cuales los mandatarios o guardadores pueden encargarse de todos los asuntos del representado (art. 2130). La ratio de la limitación estriba en la pérdida de control sobre cada una de las gestiones que se pueda realizar con tales mandatos, en especial, si se trata de un grave trámite que involucrará a una persona de manera profunda con otra (el mandatario podría reconocer por otro a cuanto hijo se le pase por delante). De tal guisa, ya se puede avizorar que la razón de la gran especificidad que exige la ley no está en una confusión entre el negocio de encomien$d a$ con el acto encomendado. Dado que se abre esta excepcional posibilidad, es necesario que la voluntad que ordena hacer el reconocimiento del hijo, conste de manera indubitada y que su cumplimiento solo pueda realizarse en una única y específica dirección, para que el acto encomendado se aproxime lo más posible a un trasvasije de voluntad; aunque sin llegar a serlo ${ }^{37}$.

Se ha dicho que tal posibilidad de diputación es bastante inútil, puesto que si se otorga de la manera antes expuesta, ya se está en condiciones de realizar el acto de reconocimiento, formalmente hablando. Así, se cumple con la formalidad exigida por el art. $187 \mathrm{n}^{\circ} 3$, de realizar la admisión por escritura pública, y con que exista la persona que tenga una voluntad de reconocer a otra específica. De hecho, podría considerarse que el mandato otorgado en aquellos términos constituiría por sí mismo un acto de reconocimien-

37 STITCHKIN (1965) nos 78 y 79. 
to ${ }^{38}$. Incluso si pensamos en una escritura pública otorgada en el extranjero, con ella también se estaría en condiciones de inscribirla en Chile, con los requisitos legales. Al parecer, lo único que impide tener a esta escritura pública como reconocimiento legalmente, estriba en que, desde el punto de vista de la teoría de los actos de habla, lo que se está realizando con la declaración de voluntad es un negocio de encomienda, esto es, que se está "mandatando" a otro para que reconozca a determinada persona que simplemente se menciona como hijo propio del mandante. En tal evento, la declaración solo está mencionando a quien se quiere que se reconozca, pues la realización es de un acto de mandato; por lo que no se realiza el acto encomendado. En consecuencia, quien extiende tal mandato, puede revocar su declaración de voluntad de encomienda y así el mandato, sin tocar ningún acto de reconocimiento (en tanto el mandato no se haya consumado).

En materia de confirmación, una consecuencia del carácter personalísimo radica en que la confirmación del reconocimiento, para sanear los vicios de que adolezca la declaración, solo puede hacerla su autor y no sus representantes legales o herederos.

4.3. Es un acto intuito persona, siguiendo la tendencia del Derecho Civil de Familia $^{39}$. En nuestra clase de casos, se refiere a que se ha realizado el acto en la consideración especial de la persona a que se dirige (dado que se trata de un acto unilateral ${ }^{40}$ ); p. ej., Gonzalo Joseph realiza el acto de reconocimiento de su hijo Juan Pablo Joseph, en atención precisa de la persona del propio Juan Pablo Joseph. La razón estriba en que lo que se pretende reconocer es un hijo, es decir, con quien se tiene una relación biológica, por lo que no da lo mismo Juan Pablo que Pedro o Matías.

Pero aquí debe precisarse algo más, para que no exista confusión en la práctica. El acto es realizado en consideración al individuo o persona física a reconocer, pero no a la cualidad de hijo del reconocido. Esta distinción tiene trascendencia en la aplicación práctica de la anulación del acto de reconocimiento por error en la persona. Lo que importa es que el reconociente identifique o le acierte al individuo que pretende reconocer. Por razón de la especial configuración voluntarista del acto de reconocimiento, que prescinde de la evidencia directa que se tenga de que, p. ej., Juan Pablo sea realmente hijo por proceso natural de Gonzalo, el error en la persona que mire a la cualidad de ser verdadero hijo por proceso natural de quien lo pretende reconocer, no es amparable por la vía de la nulidad del acto (si es que efectivamente Juan Pablo era el individuo que se pretendía reconocer). La acción de nulidad queda de esta manera restringida.

4.4. Se trata de un acto puro. No son admisibles las cláusulas limitativas y, por ende, las modalidades que alteren las consecuencias legales. Como señalé, el reconocimiento es tan solo un acto jurídico, que no establece la regulación de sus consecuencias, sino solo desencadena. Así, por una cuestión de orden público, a la admisibilidad de la paternidad la

38 Esta idea es muy antigua, y se basa en la teoría del nuncio para el mandato. Así lo sostienen en la década del diez del s. XX, Dusi y Cicu (ambos en CICU (1947) pp. 383 y 384).

39 En igual sentido, LEÓN (1991) p. 141.

${ }^{40}$ A esta clase analizada -dice DOMínguez (1977) p. 78- pertenece "gran parte de los negocios unilaterales en los que, aunque no exista contraparte, es la consideración de que los resultados del negocio van a beneficiar o afectar a una cierta persona, lo que motiva la voluntad". 
ley le atribuye directamente la constitución del estado. Ahora bien, dado que las modalidades son alteraciones de las consecuencias dispuestas por la ley, ellas se producen mediante la autonomía de la voluntad, la cual, en materia de filiación, está restringida a ámbito limitado. Por tanto, cualquier alteración debe estar especialmente habilitada por la ley. En nuestro tema, la ley solo contempla la intervención de la autonomía de la voluntad en la decisión de reconocer o no la paternidad, pero no más allá de la decisión. Luego de ella, la ley vela por la estabilidad del estado, no extendiendo la autonomía de la voluntad al campo de la vigencia del estado filial, estableciendo en consecuencia una tipicidad estricta del acto. De allí que cualquier cláusula limitativa de las consecuencias legales no sea admitida por el ordenamiento jurídico, prescribiendo el art. 189 inc. 2 parte final: "El reconocimiento es... no susceptible de modalidades" ${ }^{41}$.

De aquí deriva la segunda razón de no aceptación de la simulación. Señala E. Niño que la simulación es una modalidad de un acto jurídico, que tiene por objeto alterar las consecuencias jurídicas que deben atribuirse negocial o contractualmente. En los actos de familia, las restricciones de orden público limitan la disposición de voluntad y obliteran cualquier alteración de las consecuencias legales, por lo que no es procedente esta clase de modalidad de acto ${ }^{42}$. Así, no es posible alterar un acto de reconocimiento y la consecuencia de atribuir el estado filial, mediante la interposición de una persona real, pues el orden público bloqueará el valor del acuerdo simulatorio, al no poder regir entre las partes. Si el acto de reconocimiento se perfeccionó, entonces no hay vía legal para que el padre jurídico se deshaga de la filiación así constituida y le traspase su posición de padre de alguien a tercera persona.

Por lo tanto, el individuo mediante la declaración de reconocimiento realizado con las formas legales, crea de inmediato el acto de reconocimiento, y procederá atribuirle todas las consecuencias previstas por y de acuerdo a la ley, sin alteración de estas.

4.5. Acto solemne: No obstante el grado de autonomía que la ley prescribe en este acto, en razón del orden público involucrado, ella mantiene un fuerte control sobre la tipicidad del acto, la que está completamente cerrada. En tal sentido las vías de expresión de la voluntad están bajo el dominio abstracto del legislador, estableciendo una oferta restringida de aquellas. A efectos de lograr la mayor seriedad en la realización del acto, a fin de concretar el principio de racionalidad y de veracidad de la real voluntad, la ley establece las solemnidades para la realización del acto; por lo que la declaración de voluntad debe ajustarse completamente a las formas definidas por la ley (arts. 187, 199 bis inc. 2). Una vez concluido con la solemnidad, el acto queda perfeccionado.

\footnotetext{
41 Las “cláusulas limitativas" en el Código Civil italiano están reguladas así: "Es nula cualquier cláusula dirigida a limitar los efectos del reconocimiento" (art. 257).

42 NiÑo (1991/1992) p. 82. El argumento del orden público debe tomarse con cierta reserva. En el Derecho comparado se ha establecido, por circunstancias propias de la vida actual, situaciones de simulación en el más paradigmático negocio de familia: el matrimonio. Son los casos en que tiene por finalidad solo adquirir la nacionalidad de otro país, o bien obtener un beneficio hereditario, cuando la disposición testamentaria exige tener el estado de casado (vid. art. 123 inc. 1 CC.it.). De todas formas, como indica GALGANO (1992) pp. 530 a 532, la aplicación a este ámbito no es un asunto de explicación clara.
} 
4.6. Es un factor no jurisdiccional: El acto de reconocimiento puede darse en diversos contextos: administrativo, notarial o judicial. No obstante ello, el acto es autónomo de dichos contextos y, en especial, del judicial. Que sea un factor no jurisdiccional tiene como consecuencia que el estado filial que se adjudica es ampliamente atacable por la vía jurisdiccional, de acuerdo con las reglas generales, salvo en cuanto no puede ser modificado por su autor. A diferencia del factor jurisdiccional que tiene un rango de ataque más restrictivo, al estar protegido por la autoridad de la cosa juzgada prima facie, de acuerdo con el art. $320^{43}$.

La autonomía del factor respecto de la jurisdicción explica que no se trate de un allanamiento. Técnicamente, el allanamiento es un acto procesal que no exime al juez de la necesidad de la sentencia; solo lo exime de la prueba (si no hay normas de orden público) como señala el art. 313 del viejo CPC. Su funcionamiento en el proceso es explicado, no por ser un acto judicial, sino por la operatividad excluyente de los factores: del factor reconocimiento al factor sentencia.

4.7. Es un acto irrevocable. La revocabilidad alude a que el autor de la declaración cambia su voluntad jurídicamente manifestada y pretende deshacer lo que hizo, de acuerdo a como se hizo, esto es, con una voluntad en contrario ${ }^{44}$. En la revocación se mantienen los supuestos jurídicamente relevantes sobre los cuales se basa la declaración: los que tradicionalmente conforman la voluntad exenta de vicios; es decir, no haber sufrido error, no haber sido engañado ni haber sido forzado. En ello se diferencia de la situación de nulidad del reconocimiento, puesto que en esta, al darle relevancia a un vicio, la inicial voluntad deja de ser considerada jurídicamente desde su manifestación por su problema originario. En materia de filiación, la revocación sería una forma -indirecta- de deshacer el estado filial atacando el factor, frente a lo cual el art. 189 inc. 2 parte $1^{\text {a }}$ enuncia: "El reconocimiento es irrevocable".

4.7.1. La cuestión de la irrevocabilidad está justificada siempre en protección de los reconocidos, generalmente menores, y secundariamente de terceros a la relación, relativo a quien emite su declaración. En esta materia de filiación hay una fuerte intervención del orden público, en el sentido de que solo tiene espacio la autonomía de la voluntad, en las circunstancias en que está expresamente previsto por la ley. La resciliación unilateral o revocación se hace en uso de dicha libertad. Sin embargo, la ley solo ha previsto la opción del reconocimiento para la producción del estado filial, pero no ha otorgado facultad revocatoria ni poder para botar dicho estado; además, como se vio, el reconocimiento no es una norma que crea su régimen, sino que es la ley la que atribuye en bloque las consecuencias. Esta actuación de la ley tiene su razón en que el estado filial tiene un carácter permanente y bilateral, constituyendo un buen valor a proteger, en

${ }^{43}$ GANDUlFo (2006) pp. 83 a 85.

44 El Código Civil español no contiene referencia general a la irrevocabilidad del acto de reconocimiento, salvo una especial para el caso del testamento en el art. 764; se diferencian de aquél tanto del Codice Civile en su art. 256 y el Código Civil argentino en su art. 249, que sí contienen normas generales. 
tanto implica la estabilidad en la protección legal a un nivel profundo de las relaciones interpersonales, esto es, no solo en un contexto patrimonial, sino personal o psicológico.

4.7.2. Así, no se puede disponer de su propio acto, ni de forma unilateral ni contando con el acuerdo o respaldo de los involucrados, como si el reconocido entregase una autorización por escrito para que el reconociente revoque, o que estando fuera del plazo para repudiar, ambos acuerden de forma solemne la revocación del acto.

Esta razón se extiende aun si la declaración de reconocimiento está incluida junto a las disposiciones de un testamento. Ello porque como acto mortis causa está configurado por la ley como una manifestación de última voluntad. De allí que el testador pueda alterar el contenido del testamento cuantas veces quiera, de acuerdo al art. 999 y art. 1000. Sin embargo, la intervención del orden público limita dicha potestad, por lo que la ley pasó a prescribir expresamente: "el reconocimiento es irrevocable aunque se contenga en un testamento revocado por otro acto testamentario posterior" (art. 189 inc. $2)^{45}$.

4.7.3. La regla es que la irrevocabilidad se produce desde que el acto queda perfecto. Ello porque la tipicidad estricta del acto hace que solo haya reconocimiento cuando se ha cumplido con las formalidades por vía de solemnidad. Previo a su perfeccionamiento, su autor puede revocar cualquier declaración de voluntad. La única circunstancia en donde no puede revocarse el acto, no obstante no estar perfeccionado, es en la admisión en vía judicial. Aquí la configuración del acto está dividida en dos. En la primera parte está la formulación verbal de la admisión, y en donde la participación del sujeto activo llega hasta allí, precluyendo la opción procesal de cambio de voluntad, mientras que el levantamiento del acta está a cargo del órgano judicial. Así, al precluir su opción, por un efecto procesal, pierde la oportunidad de cambiar el sentido de su voluntad.

4.7.4. Finalmente, queda por discutir si por haber reconocimiento se afecta la posibilidad de ejercer la acción de impugnación, es decir, su legitimación activa. Este es un asunto delicado ya que hay valores contrapuestos en juego. Por un lado, está la estabilidad del estado filial y la seguridad jurídica, y, por otro, la verdad biológica. El problema se plantea para el padre o madre que son quienes pueden realizar el acto y, consecuencialmente, para el hijo.

En opinión de R. Ramos, el supuesto padre siempre estará excluido de la legitimación activa, o sea, de ser parte en un proceso, en caso de que este le haya dispensado su reconocimiento al hijo ${ }^{46}$. De tal manera que cuando ejerce dicha acción, estará actuando,

\footnotetext{
45 Es el orden público la razón de esa irrevocabilidad y no que sea una disposición, puesto que la tradición civilista nos informa de que existen declaraciones que son revocables, en particular las que se relacionan con disposición de bienes, como la que nombra un juez partidor o un albacea.

46 RAMOS (2001) p. 416. No obstante, en tal situación tendría que ejercer la acción de nulidad del reconocimiento por vicios de la voluntad, de conformidad con el art. 202.

En algunos estados de EE.UU., como Minnesota, el formulario oficial para el acknowledgement of paternity lleva la expresa advertencia de producirse la renuncia a la impugnación de la paternidad biológica.
} 
derechamente, en contra de su propio acto, que consistió en admitir de forma solemne su paternidad respecto de tal hijo, más allá de la evidencia sobre la verdad del hecho de su progenitura. Esto porque el reconocimiento no es una simple declaración, donde se debe expresar un conocimiento cierto acerca de un hecho personal histórico, como de haber engendrado a una persona, sino un acto de admisión de la paternidad basado en cierta evidencia sobre hechos conexos a la progenitura. Por tanto, el Derecho valora solo la voluntad de reconocer sobre esa evidencia de posibilidad ${ }^{47}$, esto es, la decisión de admitir la propia paternidad, configurando a este acto como un "acto de admisión". Esa especial construcción del acto genera la especial expectativa respecto de una persona como padre o madre de otra. Y dado que se trata de una relación natural permanente en el tiempo, y socialmente considerada de igual manera, la expectativa razonable que genera es de igual carácter. Es decir, nadie se constituye en padre por un rato o a plazo.

Ahora bien, la pretensión de impugnación del estado filial sostiene derechamente que el actor/reconociente no es el padre, en contra de la expectativa que él válidamente generó. Es decir, necesariamente no admite o rechaza que él es el padre, y por eso pide la investigación y actuación judicial en su reemplazo. Se pretende que el juez realice algo que él no puede hacer, precisamente porque el Derecho lo vedó, pues no podía desdecirse de la mencionada admisión. Dicha ratio legis se ejemplifica -corroborando lo dichoen la norma contemplada en el caso del art. 213 inc. 2 (de supuesto fáctico matrimonial), privando al padre de la legitimación activa de la acción de impugnación, si este "hubiere reconocido al hijo como suyo"; y ello incluso cuando operase otro factor de forma previa a aquel, excluyendo eso sí la operatividad del reconocimiento para efectos de la determinación ${ }^{48}$. Lo que sí podría alegar el padre, es la nulidad por vicios en la constitución de la voluntad, según el art. 202.

A su vez, podría agregarse como ejemplo de corroboración -aunque referido a otro tema y supuesto- el caso de la privación de la legitimación activa que hace el art. 184 inc. 2 parte final, respecto de la acción de desconocimiento de la paternidad, señalando que "el marido no podrá ejercer la acción si por actos positivos ha reconocido al hijo". En tal clase de casos, la ley pone al lado del conocimiento de la preñez, la alternativa del reconocimiento (actos positivos); es por ello que, sin perjuicio que dicha acción tenga una base meramente cognoscitiva, la ley establezca que no se podrá ejercer tal acción para destruir el factor nacimiento dentro de matrimonio o un tiempo después y así el estado filial, si es que por actos positivos admite su paternidad. Sin embargo, esta norma está más en relación con la acción de nulidad del factor reconocimiento, que con

47 Esto es lo que funda la posibilidad de que solo puede impugnarse la voluntad de reconocer por la acción de nulidad del reconocimiento, y deja fuera la acción de impugnación basada en la verdad de la relación biológica, así como cierta clase de error en los motivos basado en creer en la veracidad de la relación biológica.

$48 \mathrm{La}$ misma incompatibilidad por el principio de prohibición de ir en contra de los actos propios rige respecto de la procedencia de la repudiación. Si alguien realiza cualquier acto que suponga la creación de una situación contraria a la repudiación, queda excluido de la posibilidad de ejercerla, como cuando el hijo personalmente cita al padre a gestión judicial ad hoc de reconocimiento de paternidad (Alessandri y Corral, ambos en CORRAL (1999) p. 61). Tal principio se manifiesta en el art. 192, que prohíbe repudiar al hijo que "durante su mayor edad, hubiere aceptado el reconocimiento en forma expresa o tácita". 
la acción de impugnación del estado filial. En efecto, tanto la de desconocimiento como la de nulidad tienen como pretensión directa el factor de determinación y no el estado filial. Ahora bien, ello debería poner nuestra solución legal a la par de la correspondiente de la acción de nulidad (que no admite tal limitación). Pero la gran diferencia está en que, si bien ambos indirectamente son medios de destruir el estado filial, la solución del art. 184 inc. 2 no puede aplicarse a la nulidad. Por un lado, la solución en el caso de la nulidad supone un ataque a un momento intelectualmente previo e indispensable a la admisión misma, que es cuando se forma la voluntad de reconocer, por lo que mal podría obstar el propio reconocimiento. Por otro, aquello no está presente en la acción de desconocimiento de la paternidad, en la cual el reconocimiento actúa por expresa disposición legal de manera postrera, para sanear una cierta situación, de posible desconocimiento de la preñez, y de que el menor pueda no ser del marido, situación por la cual la ley debió contemplar expresamente esta solución ${ }^{49}$.

Por tanto, como ha dicho la Corte Suprema -conociendo de un recurso de casación, en causa sobre juicio de impugnación de paternidad "Cañas Nielsen con Muller Barrientos"-, "los jueces del fondo han establecido que la menor nació el 2 de diciembre de 1998 y que al ser inscrita fue reconocida por ambas partes como hija de ellos, quedando así determinada legalmente la filiación... de dicha menor, de donde se desprende que de conformidad a lo que dispone el artículo 189 inciso $2^{\circ}$ del Código..., resulta categórico que el mencionado reconocimiento es irrevocable [por el padre], de ahí que la casación en estudio no pueda prosperar adoleciendo de manifiesta falta de fundamento" 50 . Como se señaló anteriormente, este no es solo un problema de irrevocabilidad, sino más profundo y amplio alcance: de no poder ir en contra de un acto propio válido de admisión ${ }^{51}$, lo que incluye la idea de irrevocabilidad, pero va más allá, como en el caso en cuestión en que sin revocar pide al tribunal que destruya el estado filial, con la pretensión de que no es padre de alguien.

${ }^{49} \mathrm{La}$ Corte de Apelaciones de Arica en el caso "Vásquez Vargas con Vásquez Alcayaga" ha apuntado en similar línea -por la pluma del juez Díaz Cruzat (redactor) - agregando que: "Esta irrevocabilidad tiene su origen en el hecho que la ley implícitamente considera que el reconocimiento conlleva una renuncia al derecho de reclamar [contra] la filiación. Al respecto, la historia fidedigna de la ley aclara estos conceptos. En efecto, en las sesiones de la Comisión del Senado, al discutirse el inciso $2^{\circ}$ del artículo 184, se dijo: 'El carácter copulativo que tienen los requisitos de que el marido no haya conocido la preñez al tiempo de casarse y que desconozca judicialmente su paternidad, para que se aplique la presunción de paternidad; y, por otro lado, impidiéndole directamente el ejercicio de esta acción si por actos positivos ha reconocido al hijo después de nacido, en vez de declarar que se entiende renunciada la acción'. (Código Civil Actualizado. Septiembre 2000. Diario Oficial. Páginas 68 y 69)". Sentencia de 28 de abril del 2003, rol 8.819-02, en www.lexisnexis.cl ( $\mathrm{n}^{\circ}$ identificador 28789).

50 Sentencia del 3 de octubre de 2002, rol 2.646-02, en www.lexisnexis.cl ( ${ }^{\circ}$ identificador 26031); también así la Corte Suprema en el caso "Vásquez Vargas con Vásquez Alcayaga", sentencia de 30 de octubre del 2003, rol 1.994-03, en www.lexisnexis.cl ( $\mathrm{n}^{\circ}$ identificador 28789).

51 Tanto Albaladejo como Díez-Picazo eran de la opinión, en el antiguo modelo, que el principio del acto propio no alcanzaba para privar de la legitimación, ya que siguiendo la teoría del título de legitimación, el acto de reconocimiento era inválido si el reconociente no es el padre. Así que asimilaban la pretensión de nulidad a la de impugnación, por lo que señalaban que si el Tribunal Supremo niega lugar a la privación de la legitimación activa de la acción de nulidad, entonces también corría lo mismo para la de impugnación (ambos en DíEZ-PICAZO (1973) p. 141). 


\section{SUJETOS}

\subsection{PERSONA QUE PUEDE RECONOCER}

La coherencia con la verdad biológica y el voto de confianza en pro de la responsabilidad de los individuos reconocientes (puesto que se trata de una admisión o proclamación de la propia paternidad o de la maternidad), hace que el ordenamiento jurídico delinee esta figura en orden a que toda persona que tenga la convicción de ser progenitor de otra pueda reconocer. La regla es la amplitud de la capacidad para reconocer.

Por virtud del principio de verdad biológica, no existe limitación en cuanto a las relaciones de parentesco que puedan haber entre el padre o la madre: así, por ejemplo, podría reconocer un padre que tuvo una relación incestuosa. Tampoco lo hay respecto de si los padres están casados con otras personas que no sean padres biológicos del reconocido. Igualmente, se puede decir que, también lo pueden realizar los padres que están casados entre sí, como hemos visto, siempre y cuando en la situación no se dé la operatividad excluyente de factores.

La facultad de reconocer es de carácter personalísimo del titular, salvo expresa autorización legal ${ }^{52}$. La regla del derecho de la filiación chileno es que los incapaces no pueden ejercer sus derechos personales por el ministerio de su representante legal. Sin embargo, es necesario, como señala R. Abeliuk, pasar a distinguir ciertas situaciones ${ }^{53}$ :

Para el incapaz absoluto, la regla es que no puede reconocer en ningún caso, mientras sea incapaz absoluto, ya que técnicamente se considera que esta clase de incapaces no tienen voluntad jurídicamente eficaz, por lo que no hay posibilidad de declaración. La madre incapaz absolutamente puede quedar ligada a través de otra técnica: el factor parto.

El incapaz relativo:

El menor adulto: puede hacerlo personalmente, sin autorización de terceros, ya que técnicamente el incapaz relativo tiene voluntad para el Derecho -aunque ella sea no del todo perfecta para ciertos respectos-. Así, la ley dice: "El menor adulto no necesita de la autorización de sus padres... para reconocer hijos” (art. 262).

El disipador interdicto también puede hacerlo personalmente, sin mayor autorización, en razón de que su interdicción rige para actuaciones de orden patrimonial y no de carácter personal. Igual solución concreta el Derecho para poder repudiar, lo que se corrobora en el art. 191 inc. 3.

El representante convencional. Puede realizarse el reconocimiento por medio de mandato (art. 190: "El reconocimiento... podrá realizarse por medio de mandatario"), siempre que esté especialmente facultado para ello, constando por escritura pública. Dicho mandato debe insertarse en el caso del reconocimiento por escritura pública. Más compleja se vuelve la admisibilidad de este acto, a causa de la ratio legis de la figura legal del reconocimiento en vía judicial, lo que se verá más adelante.

52 GANDUlfo (2006) pp. 38 y 39; y AbeliuK (2000) no 55, p. 84, con serias contradicciones, como en el no 58 , pp. 89 y 90 .

53 Aquí voy a seguir en principio a ABELIUK (2000) no 55, pp. 84 a 86. 


\section{Posibles limitaciones:}

Dado que el reconocimiento es un factor de determinación que pertenece a la filiación originada en procedimiento biológico-natural, no sería admisible, si, de acuerdo a las circunstancias, esta es evidentemente imposible: p. ej., reconociente y reconocido tienen la misma edad, una edad similar con diferencia, v.gr., de 5 años (debe tener al menos una diferencia que suponga aptitud para procrear) o bien el reconociente es menor que el reconocido. Es físicamente imposible que se constituya el criterio natural $y$, por tanto, inadmisible la filiación que proceda de tal criterio. Asimismo, no puede reconocer como madre un hombre (solo puede acceder al preciso estado de padre ${ }^{54}$ ). Todo ello no alcanza a ser protegido por esta figura legal del reconocimiento de acuerdo a sus fundamentos.

Además, es necesario tener en cuenta que tampoco es admisible esta clase de actos cuando la declaración es vacía y no se basa en una convicción de paternidad. Y esto tiene que ver con la técnica de redacción de documentos y del fundamento de este factor. En tal sentido, si bien es cierto que la decisión de reconocer se basa en una convicción sopesada en razones de la posibilidad de ser padre o madre, no es forzoso que cuando se realiza el acto, el padre o madre deba expresar sus razones. Sin embargo, eso no quiere decir que no pueda emitir sus razones. Entonces, es posible que el sujeto activo del acto sostenga que reconoce al hijo de una desconocida y afirme que jamás tuvo relaciones sexuales de ninguna clase con ella. Ello se opone a la construcción misma del acto de reconocimiento, puesto que este se basa en una convicción racional, que es lo que le abre la posibilidad de autonomía a los individuos en materia filial y configura el acto de admisión misma.

En similar situación queda el pretendido reconociente, cuando afirma reconocer el hijo, sosteniendo razones que no pertenecen a este criterio natural, sino que las aduce de otro; p. ej., como si alegase únicamente razones sociales, de haber tratado a quien se pretende reconocer como padre durante mucho tiempo, o pretender reconocer a un menor respecto del cual está tramitando la adopción, para ahorrarse los pasos legales. Igual razón cabe si el menor tiene su origen en la reproducción asistida, declarando el padre simplemente que son suyos los espermios. Cada uno de los criterios tiene sus particularidades y problemas diversos, a los cuales la ley le atribuye diversas soluciones adecuadas, más o menos, a dichos problemas, por lo que el trasvasije de figuras es en principio vedado, como en el caso del reconocimiento ${ }^{55}$.

En todos estos casos, el competente funcionario que reciba la declaración debe rechazar la conclusión del acto de reconocimiento, y aun el oficial del Registro Civil debe negar la inscripción y o subinscripción del mismo, si es que el acto estuviese perfeccionado.

\subsection{PERSONA QUE PUEDE SER RECONOCIDA}

En conformidad con el principio de igualdad y de facilitar el establecimiento de la filiación, se pretende que esta posibilidad de reconocer y así determinar el estado, se

\footnotetext{
54 GANDULFO (2006) pp. 51 y 59, en especial, la nota 35.

55 Vid. sobre los procedimientos, sus criterios para dar origen y sus regímenes, GANDULFO (2006) pp. 56 y 57.
} 
pueda extender respecto de cualquiera sin distinción en principio, salvo algunas limitaciones estructurales del sistema. Así, en esta materia, la figura se caracteriza por una amplitud de la posibilidad de ser reconocido. La regla es que pueda ser cualquiera que haya sido, pueda ser o actualmente sea persona: menor o mayor de edad, nasciturus o ex post mortem (hijo muerto).

5.2.1. El nasciturus, sí puede serlo56; aunque cabe la duda de por qué se puede reconocer, esto es dirigir un acto para producir las consecuencias jurídicas, respecto de quien no tiene existencia legal, aunque sí vida. La razón está en que la ley, en general, reconoce la existencia natural, aunque de forma muy atenuada, de quien tiene vida pero no ha nacido, dejando en suspenso la titularidad de los derechos o el régimen de los negocios y actos dirigidos a tal dirección (art. 77). Por ejemplo, extender las facultades de patria potestad a los derechos eventuales del nasciturus (art. 243 inc. 2) o destinar un curador de bienes en subsidio (art. 485) o bien para validar la donación entre vivos (art. 1390 inc. 2) o el fideicomiso (art. 737).

En nuestra clase de casos debe entenderse que el ordenamiento civil admite el acto de reconocimiento, el que está perfecto y no puede revocarse; ni la eventual muerte del reconociente puede afectarlo, pero deja en suspenso la atribución del estado, para el evento de cuando tenga existencia legal quien se espera que nazca ${ }^{57}$. Porque de no nacer vivo el hijo, entonces se entenderá no haber intervenido jamás en la vida jurídica como sujeto de derechos civiles (art. 74 inc. 2, y los derechos que le hubiesen correspondido, pasarán a quienes corresponda en Derecho, según el art. 77 p. $3^{a}$ ). Para el evento de nacer vivo, la ley le atribuye al acto de admisión la consecuencia del estado filial y retrotrae el status filii a la época de la concepción, de acuerdo con el principio de retroactividad del art. 181, el que está basado, precisamente, en el criterio de la concepción, que sí puede satisfacer el nasciturus.

Ello concuerda con la evolución jurídica de este tipo de casos, tanto legal como jurisprudencial. En el Código original se aludía expresamente a "los hijos nacidos" cuando hablaba del reconocimiento; aunque se sostenía por F. Fueyo que, ya en aquella época, la mayoría entendía que de todas maneras era aceptable el reconocimiento al nasciturus. Sin embargo, para eliminar los obstáculos al reconocimiento del nasciturus, la Ley 10.271 eliminó la alusión a "los hijos nacidos" así como la notificación y la aceptación, por lo que la decisión legislativa se inclinó favorablemente a darle cabida a tal opción (M. Somarriva) ${ }^{58}$.

Desde el punto de vista pragmático, la permisión analizada da una vía de solución a las personas que estén imposibilitadas de realizar el acto después del nacimiento de

\footnotetext{
56 En el mismo sentido, Corral (1999) p. 59, quien señala que "del art. 181 CC. que dispone la retroactividad de los efectos a la época de la concepción del hijo parece deducirse la factibilidad del reconocimiento".

${ }^{57}$ La tal suspensión es concordante con la necesidad de subinscripción en la partida de nacimiento, la que solo se puede efectuar una vez nacido e inscrito.

58 FUEYO (1959) $n^{\circ} 879$, p. 435. Sostiene Fueyo que la práctica hacía notificar el reconocimiento al curador de los derechos eventuales del hijo que está por nacer. SOMARRIVA (1955) pp. 188 y 189.
} 
quien se pretende reconocer; p. ej., quien esté aquejado por una enfermedad terminal y no tenga una proyección de vida más allá de unos meses, o bien del que deba someterse a una intervención médica de bajas probabilidades de sobrevivencia, o bien para quien debe salir de viaje y no se espera que vuelva, o bien, para que sea considerado como futura carga patrimonial en el juicio de compensación económica. En todos dichos casos y otros, si no se adoptase la solución propuesta, el Derecho dejaría en franca desprotección filial al hijo que se espera ${ }^{59}$.

No obstante, para proceder a dicho reconocimiento, el concebido no nacido solo puede ser individualizado por referencia a la individualización de la madre que lo trae en su vientre ${ }^{60}$.

5.2.2. El hijo muerto, sí puede serlo, en razón del art. 193. Pero nuevamente la pregunta es qué fundamenta tal decisión, si el muerto ya no es persona natural (y carece personalidad jurídica), ni jamás podrá volver a serlo, y el acto se dirige en tal dirección. La razón está en la consideración de que alguna vez fue persona natural, y pudo intervenir en general en la vida jurídica del sistema jurídico chileno. De allí que los vivos puedan tener diversos e importantes intereses en esa persona, por lo que la ley estimó como suficiente dicho estado pretérito de existencia legal y excepcionalmente permite que el acto se dirija a él; aunque sí la consecuencia legal de atribución del estado se va a retrotraer a cuando tuvo personalidad jurídica el muerto, hasta llegar al tiempo de la concepción como indica el art. 181. Esto es lo que está tras la suposición del art. 193, en orden a que "si es muerto el hijo que se reconoce...".

Esta posibilidad es un tema delicado y puede prestarse para fraudes. El estado filial que se constituye tiene vigencia retroactiva de acuerdo al art. 181: "La filiación produce efectos civiles cuando queda legalmente determinada, pero estos se retrotraerán a la época de la concepción del hijo", lo que puede prestarse a ciertos fraudes, en particular, en el orden de los derechos sucesorios. Si la libertad para reconocer es bastante amplia, entonces se podría pretender establecer la filiación con alguien que dejó una herencia cuantiosa y que no tuviese descendientes (art. 988), a efectos de ponerse en el orden sucesorio abintestato (art. 989 y ss.) o de los legitimarios (art. $1182 \mathrm{n}^{\circ}$ 2), sin que hubiese limitación para ello. El Derecho comparado, conociendo esta situación, ha establecido varios tipos de limitaciones, afectando incluso a la posibilidad de establecer una filiación verdadera ${ }^{61}$. Las soluciones del ordenamiento jurídico chileno podemos configurarlas como las siguientes:

\footnotetext{
59 Este reconocimiento es suficiente para constituir un germen de derecho, productor de ciertas consecuencias jurídicas, como legitimar el interés del padre reconociente en ciertas acciones de protección del nasciturus, así como la de considerarlo como carga del padre de contexto extramatrimonial, a efectos de fijar una eventual compensación económica del padre demandado en juicio de divorcio.

${ }^{60}$ Esta es la razón, por la cual en el Derecho comparado se establece una excepción, a la no divulgación del otro padre en el acto unilateral de reconocimiento. Así, el CC. del Perú dispone en su art. 392 que cualquier información sobre el nombre del otro padre se tendrá por no puesta, salvo en el caso del padre que reconoce al hijo simplemente concebido. Lo mismo dispone el art. 258 inc. 2 parte $2^{\text {a CC.it. }}$

61 El Derecho comparado contempla ciertas clases de cláusulas de previsión de cualquier fraude que pudiese darse, que no se contemplan en Chile de manera especial. Dado que el hijo muerto puede haber participado en la vida jurídica, acumulando una gran fortuna, entonces tal haber puede ser objeto de la
} 
A) Se dispuso una norma especial para el ius personarum. Se limita la adquisición de derechos cuya titularidad pertenezca a terceros. Es decir, sin afectar al reconocimiento mismo ni al estado filial, restringe la pérdida de los derechos que, por la vigencia retroactiva del estado, les correspondería perder a terceros adquirentes, previos a la subinscripción del reconocimiento. Y ello lo hace de dos maneras: distingue respecto del momento de: 1) la constitución del estado filial y 2) el de la subinscripción.

1) En el primer caso, respecto al momento de la constitución del estado filial, veda al reconociente el acceso a los derechos a la sucesión, que sean adquiridos por terceros sin distinción, de forma previa a la determinación legal de la filiación; esto es, cuando ha precedido a la determinación, la aceptación del heredero o presunto heredero (art. 957). De tal guisa, enuncia el art. 181 inc. 2 parte $1^{\text {a: }}$ "No obstante, subsistirán los derechos adquiridos y las obligaciones contraídas antes de su determinación". Tal norma abarca todos los derechos, incluyendo los sucesorios.

2) Para el segundo, esta limitación rige hasta el momento de la subinscripción del reconocimiento y se inicia desde la determinación legal de la filiación. Esta circunstancia es bastante excepcional, pues si ya se tiene constituida la filiación, entonces lo que correspondería de acuerdo con el mecanismo legal es la no intervención de los terceros en la imputación de los derechos que corresponden a quien detente una determinada filiación. Es por ello que la ley recurrió a un criterio más fuerte y restringido, que proteja a ciertos terceros que se encuentren en determinadas circunstancias. Desde la perspectiva de configurar el mecanismo de protección al fraude sucesorio, podemos ver que los terceros adquirentes de los derechos sucesorios quedan protegidos, si es que están de buena fe en la adquisición de aquellos: si no sabían, antes de aceptar, que existían estas personas posibles herederas. Así reza el art. 189 inc. 3: "El reconocimiento no perjudicará los derechos de terceros de buena fe que hayan sido adquiridos con anterioridad a la subinscripción de este al margen de la inscripción de nacimiento del hijo". No estarían protegidos los terceros que sabiendo que se ha constituido legalmente la filiación, proceden a aceptar la herencia para obliterar la entrada en la titularidad de los derechos sucesorios por parte del reconociente.

La ley, en todo caso, protege a los hijos en sus derechos sucesorios, atribuyéndolos con vigencia retroactiva hacia el tiempo de la concepción (para efectos del art. 962), sobreponiéndose así a los derechos adquiridos por terceros, aun de buena fe. Así se establece una contraexcepción general a las situaciones de los terceros. El art. 181 inc. 2 parte $2^{\text {a }}$ dispone que, no obstante los derechos adquiridos de terceros, previos a la constitución del estado filial, de todas maneras "el hijo concurrirá en las sucesiones

codicia de terceros para poder adquirirla por herencia. Así el art. 249 CC.arg. establece que: "El reconocimiento del hijo ya fallecido no atribuye derechos en su sucesión a quien lo formula, ni a los demás ascendientes de su rama”. El Código del Perú lo cautela con una cláusula de protección vía prelación sucesoria: artículo 394: "Puede reconocerse al hijo que ha muerto dejando descendientes". Igual vía toma el Código español: "El reconocimiento del ya fallecido solo surtirá efecto si lo consintieren sus descendientes por sí o por sus representantes legales" (art. 126). Finalmente, el Derecho italiano lo contempla solo para favorecer a los descendientes del hijo muerto: "Puede también tener lugar el reconocimiento del hijo premuerto, a favor de sus descendientes legítimos o de sus hijos naturales reconocidos" (art. 255 CC.it.). 
abiertas con anterioridad a la determinación de su filiación, cuando sea llamado en su calidad de tal". La razón de la protección a los hijos y no a los padres está precisamente en que los padres tienen a su disposición el mecanismo de reconocimiento, lo que puede prestarse para el fraude sucesorio, no así los hijos, que ocupan un rol pasivo en la configuración de este factor.

La razón de la primacía de esta norma, por sobre la del art. 189, estriba en la vigencia retroactiva del estado filial. En efecto, la retroactividad busca realizar un aspecto de justicia respecto de quien siempre debió ser considerado padre o hijo y que por alguna razón no siempre lo fue, al menos en el contexto del criterio-base biológico. De ahí que la ley atribuya los derechos que se imputan por razón de filiación, como los derechos sucesorios, en consideración de que les corresponderían estos a los hijos, si hubiesen tenido la calidad de hijos desde el principio ${ }^{62}$. Así, tal consideración se sobrepone a la situación más difícil de cuando no se tiene la filiación, como el caso del art. 181 inc. 2 parte $1^{\text {a }}$, no habiendo mayor peso en una situación similar como la que contempla el art. 189. Por otro lado, no tener esta solución violaría la garantía constitucional de la igualdad en el ámbito de la concurrencia de los hijos en las sucesiones. En un caso particular, siendo todos hijos, algunos no podrían concurrir, pues les faltaría la inscripción o subinscripción, teniendo tal hipótesis esta consecuencia discriminadora. $\mathrm{Y}$, finalmente, parece haber un subprincipio de nuestra legislación, de favorecer la participación de todos los hijos en las sucesiones.

Todo ello es sin perjuicio de situaciones de extrema cantidad de tiempo transcurrido en la titularidad de los derechos. Para la estabilidad de las expectativas, entonces entra a regir las reglas de la prescripción.

B) Aparte de lo expuesto, se establece que los herederos del hijo muerto que es reconocido, pueden repudiar el reconocimiento y rechazar de esta manera la filiación así constituida. Sin embargo, la pregunta que cabe es ¿todo heredero puede repudiar, incluso una persona meramente jurídica? En principio, una intuición lectora podría a llevar a la posición afirmativa: "Si es muerto el hijo que se reconoce... sus herederos podrán efectuar la repudiación dentro del año siguiente al reconocimiento". Sin embargo, si la repudiación tiene una justificación filial, esto es, para proteger a los descendientes de filiaciones indeseadas, entonces la idea del heredero se ve restringida exclusivamente a la interpretación justificada de esta norma: que el heredero de que habla el art. 193 es el descendiente. Los herederos no descendientes quedarían protegidos por un mecanismo más complejo, el de los directa o personalmente afectados con la filiación: las normas sobre impugnación directa de la filiación, como en la paternidad que se halla en una situación extramatrimonial o bien incluso cuando se trate de una paternidad en un contexto matrimonial sobrevenido (art. 215 inc. 5), ya que sin esta previsión se podría estar amparando eventuales fraudes. Corrobora la aseveración anterior, el enunciado legal del mencionado inciso 5º,

\footnotetext{
62 El derecho de alimentos que podría también atribuirse de manera retroactiva, está limitado, pues este jamás tiene vigencia retroactiva, sino que se deben desde que se demanda: art. 331: "Los alimentos se deben desde la primera demanda". El resto de los derechos imputados en base al estado filial no tiene sentido que tengan titularidad retroactiva.
} 
que dispone a continuación del inciso que habla sobre situación de sobrevenida matrimonialidad (inc. 4), que: "También podrá impugnar la paternidad...", es decir, no solo en los casos de sobreviniencia sino también de extramatrimonialidad, y luego da una regla especial de conteo de plazo de caducidad, que no se contenía en ninguna de las dos situaciones antes mencionadas: los dos años plazo. Si se hace extensible a la madre que reconoce las reglas de la impugnación de la maternidad (art. 217 a 219), entonces se le hace también vigente la norma de los perjuicios sucesorios del art. 218.

5.2.3. Limitación general: No vale respecto de personas con filiación distinta, legalmente determinada (art. 189). Ello porque ya tienen un estado, el de hijo (art. 33), que es permanente o constante ${ }^{63}$. Para alterarla requiere poner en marcha la función jurisdiccional constitutiva. Las vías son las acciones conjuntas de impugnación y reclamación de estado: art. 208.

La sanción: para H. Corral se trataría de la inexistencia ${ }^{64}$.

Por mi parte, estimo que el acto existe, pero simplemente la ley no lo estima admisible como factor y derechamente no le atribuye, de plano, la consecuencia juridica del estado filial a la segunda declaración. El art. 189 lo que concreta es la operatividad excluyente de los factores de determinación en relación a la constitución del estado filial, es por ello que se norma que "no surtirá efectos", y el único "efecto" atribuido, en relación con la operatividad excluyente, es la imputación del estado filial ${ }^{65}$. De esta manera, tal acto queda como un simple hecho o acto del hombre; y, como acto existente, podría servir en otra oportunidad, como medio probatorio para una eventual acción de reclamación, en especial, una entablada por el hijo.

\section{EXPRESIÓN DE VOLUNTAD}

A. Debe ser un acto de expresión directa. Una declaración de voluntad, una decisión, que pretende dejar determinada la filiación de acuerdo a la ley. No basta con la mera afirmación de la posibilidad de ser tal, a través de una relación causal probable. Como todo acto jurídico debe haber una voluntad de querer revelar de forma pública, que una persona es hijo del autor de la declaración o del mandante, para desencadenar la consecuencia jurídica filial. Art. 187 inc. 1: "El reconocimiento del hijo tendrá lugar mediante declaración formulada con ese determinado objeto...”, y el art. 213 inc. 2: “... si el padre hubiere reconocido al hijo como suyo en su testamento o en otro instrumento público".

B. Reconocimiento incidental. Es una declaración que aparece en un documento público que no tiene por objeto directo realizar este tipo de acto o declaración de admisión, aunque enuncie de forma evidente la propia maternidad o paternidad, v.gr.,

${ }^{63}$ Sobre la operatividad excluyente de los factores en relación con el estado filial: GANDULFO (2006) pp. 86 y ss.

${ }^{64}$ CORRAL (1999) p. 58.

65 GANDULFO (2006) p. 89. 
en una escritura pública donde otorgue ascenso y se afirme ser padre ${ }^{66}$. Se discute su validez por no adecuarse al carácter directo del acto. Lo que está en juego aquí es la consistencia que tenga el carácter incidental con la configuración del reconocimiento. La calificación del reconocimiento es de acto jurídico, y como tal es condición necesaria que la voluntad esté dirigida a desencadenar la atribución del estado filial. Si se extiende la idea al reconocimiento incidental, esto es al que no está dirigido a la constitución del estado filial, entonces la calificación se trastroca, y el factor reconocimiento se configuraría como un hecho jurídico del hombre, ya que la voluntad dirigida a desencadenar la producción del vínculo jurídico filial no sería condición necesaria, sino una mera contingencia, así como para la atribución de una pena lo es para el delincuente que desea la consecuencia penal ${ }^{67}$. Además, si se combina con la tesis de las locuciones ejecutivas de J.L. Austin, lo que está presente allí no es la realización de un reconocimiento, sino que lo que está realizando, es otro acto que contiene una mención acerca de un supuesto hijo ${ }^{68}$. Según Ramos, si, v.gr., se hace en una escritura de mandato: "JJ. confiere poder a su hijo $Z Z$...", no vale porque no tiene por objeto reconocerle sino conferirle poder a alguien ${ }^{69}$. Tampoco vale, según lo dicho desde antiguo por la Corte Suprema, el que en el testamento se refiera a hijos ("ilegítimos"), instituyéndolos como herederos universales y nombrándoles guardador ${ }^{70}$.

\section{FORMALIDADES}

\subsection{FORMALIDADES POR VÍA DE SOLEMNIDAD}

Dado que en esta materia se halla involucrado el orden público y la pretensión legal de que el acto sea meditado y fehaciente en lo posible, acarrean como consecuencia que para la configuración de este factor el tipo legal del acto esté completamente cerrado, por lo que la declaración de voluntad debe ajustarse completamente a las formas objetivas que expresa y taxativamente dispone la ley, para así lograr la calificación jurídica de acto de reconocimiento y perfeccionarse ${ }^{71}$.

Si no se sigue la solemnidad requerida, entonces no se tendrá tal acto jurídico. Sin embargo, es menester notar que el reconocimiento no formal funciona como medio para corroborar una pretensión en un proceso de filiación ${ }^{72}$ y para excluir la acción de impug-

\footnotetext{
${ }^{66}$ En el Derecho argentino se contempla uno de los pocos casos, en que se prescribe la posibilidad jurídica de que el reconocimiento se haga de forma incidental. El art. $248 n^{\circ} 3$ del CC.arg. dispone: "El reconocimiento del hijo resultará: de las disposiciones contenidas en actos de última voluntad, aunque el reconocimiento se efectuara en forma incidental'.

$67 \mathrm{La}$ única voluntad sería la dirigida a realizar el acto en general que contenga la incidencia. AGUILÓ (2000) cap. III, n $^{\circ}$ 2.3. señala, creo de forma correcta, que lo "relevante, y en ello radica la clave de la distinción, está en que el resultado institucional se produzca con independencia de que lo quiera o no el sujeto que ha actuado intencionalmente”.

${ }^{68}$ El libro de AUSTin (1990). Y, también, la posición de Ross (1974) pp. 169 y ss.

${ }^{69}$ RAMOS (2001) no 506, p. 387.

${ }^{70}$ Sentencia de 19 de diciembre de 1939, RDJ., tomo 37 (1939), sección 1a, p. 483.

71 Sobre la formalidad de cierre, SUMMERS (2001) pp. 133 y 134.

72 Díez-Picazo y Gullón (1992) p. 264.
} 
nación, según el art. 213 inc. 2. Dependiendo de la subclase de acto de que se trate, se exige una mayor o menor solemnidad, por lo que se debe distinguir entre el reconocimiento por acto inter vivos o mortis causa; aunque también se puede clasificar según la simplicidad de constitución del acto, entre las formas no judiciales y las judiciales.

\section{a) Reconocimiento por acto inter vivos extrajudicial:}

Esta clase de acto debe constar en un instrumento público necesariamente. Por ello participan en él el reconociente y el competente funcionario que deja testimonio del acto.

\section{a.1. Inscripción de nacimiento}

i. Por la consignación del nombre del padre o madre a pedido del correspondiente padre, al momento de practicarse la inscripción del nacimiento (art. 188). Esta es la forma más expedita de proceder al reconocimiento, pero de configuración legal más compleja; por ello se ha llegado a dudar de su cariz de acto de reconocimiento en puridad. Pero, en verdad, es una real y legítima forma de realizar el acto de reconocimiento. La posibilidad de realizar este acto jurídico depende con mucho del Derecho. Es la norma la que constituye la instancia de realización, estableciendo el escenario para constituir el acto institucional. Así la declaración no se produce en el aire, sino que en un determinado contexto: al momento de practicarse la inscripción de nacimiento, ante el oficial del Registro Civil. Ahora bien, como todo reconocimiento, este debe ser un acto intencional, por lo que en ese contexto, y sabiendo las consecuencias, el pretendido padre pide que se consigne su propio nombre en la inscripción del hijo como padre. Así, p. ej., Luis Carillón al inscribir a su hija Aranza Carillón ante el oficial del Registro Civil, le expresa que quiere que se le consigne en la partida su nombre Luis Carillón figurando como padre de Aranza. Dicha petición es el acto mediante el cual se reconoce en este contexto a un hijo, así como el "sí quiero" es el acto mediante el cual una persona realiza el acto de casarse con otra, más otros requisitos, en otro determinado contexto. Es decir, no solo informa que quiere que quede consignado su nombre en la inscripción, sino que derechamente está reconociendo un hijo, mediante la forma descrita por la ley. Acto seguido, debe recogerse dicha declaración, consignando el nombre del padre y su petición en la inscripción de nacimiento.

Dado que se trata de un acto personalísimo, según hemos visto, la petición de consignación no puede ser de uno cualquiera de los padres, y tener consecuencias dobles. Cuando la ley se refiere a: "petición de cualquiera de ellos", se refiere a que cada padre reconoce su paternidad.

Finalmente, dado que este es un acto jurídico, entonces él debe ser intencional, esto es, pedir la consignación con la voluntad de que quede constancia del reconocimiento. Por ello no cabe que se consigne el nombre del padre, si no es bajo esa condición. Si faltase el requisito intencionalidad o la voluntad estuviere viciada, porque fue inducido a error, entonces tal declaración no tendrá valor y será impugnable directamente por medio de la acción de nulidad. Corrobora tal aserto, el Código Civil cuando enuncia especialmente, aparte del art. 1682, que el reconocimiento será anulado por error fuerza o dolo que influya en la formación de la voluntad (art. 202). 
ii. Declaración en la inscripción de nacimiento del hijo. La declaración debe estar recogida en la partida misma. El oficial del Registro Civil deberá dejar testimonio en la inscripción del nacimiento, las declaraciones que los padres formulen como reconocimiento (art. 32 inc. 2 LRC.). En este caso, dice Ramos, solo podrá realizarse la declaración al momento de inscribir el nacimiento. La razón está en que la ley oblitera la posibilidad de modificar la inscripción una vez hecha, si no es por la vía de la sentencia judicial (art. 17 LRC.) ${ }^{73}$. La diferencia con la forma anterior, es que esta no se realiza de forma simplificada, sino que haciendo la declaración completa de reconocimiento, esta vez con la fórmula directa.

iii. Se ha sostenido la tesis de que esta forma de admisión puede realizarse en una segunda inscripción de nacimiento de una persona, sin decreto judicial; esta segunda se efectuaría para realizar especialmente la opción de reconocer vía art. 187 no 1 . Así, si es que en la inscripción de nacimiento no se pudo realizar el acto de reconocimiento, se podría extender, simplemente, otra para lograr realizarlo. Esto se basa en tres argumentos: $1^{\text {o }}$ Se posibilita la realización por la ausencia de norma prohibitiva. No hay disposición legal expresa que prohíba al padre o madre hacer una nueva inscripción de nacimiento, con el objeto de reconocer y tampoco es dable presumir la existencia de esa prohibición. $2^{\circ}$ La norma de la inscripción tiene en vista facilitar, en forma práctica, la constitución legal de la familia, así como de la determinación filial. $3^{\circ}$ Una segunda inscripción respecto de una persona que no tenga determinada la filiación, no contiene dato alguno que contradiga o tienda a alterar la inscripción anterior, practicada sin mencionar el nombre del padre, como para que sea necesario decreto judicial según el art. 17 LRC. ${ }^{74}$.

Por mi parte, creo que esta tesis no puede prosperar.

$1^{\text {o }} \mathrm{Si}$ bien es cierto que con inteligencia se evita la objeción meramente formal de que podría haber otra prohibición en alguna parte ${ }^{75}$, no se da cuenta de que nos encontramos ante una situación que no puede resolverse con ese simple argumento de que existe la posibilidad de hacer ante la falta de prohibición. Las solemnidades son formas de manifestar la voluntad, es decir, poderes para la expresión de la voluntad ${ }^{76}$. Ellas son de Derecho

\footnotetext{
73 RAMOS (2001) no 506, p. 388 (también así, pero muy escueta, VELOSO (2001) p. 115).

${ }^{74}$ Corte Suprema, sentencia 19 de mayo de 1958, RDJ., tomo 55 (1958), 2a parte, sección 1a, pp. 92 y ss. El caso que resolvió era a raíz de una posesión efectiva, en que una persona la pedía respecto de los bienes de su padre. En su primera inscripción no aparecía con padre reconociente. Su padre la había reconocido solo en una segunda inscripción de nacimiento, que este había pedido al Registro Civil especialmente para poder reconocerla en ella, y que el servicio se la concedió (ABELIUK (2000) no 53, p. 80).

75 Con ello evita la ambigüedad del principio de probibición, el que, según Alchourrón y Bulygin, se refiere a que "todo lo que no está prohibido, está permitido". La ambigüedad es la siguiente: si este enunciado tiene el sentido de ausencia de prohibición, entonces el principio es trivial, porque solo dice que "lo que no está prohibido", "no está prohibido", sin dar mayor referencia. Pero si quiere significar que existe una norma que permite la conducta, entonces el principio es lógicamente falso, pues del mero hecho de la ausencia de norma prohibitiva, no se infiere la existencia de una norma permisiva; es decir, se pierde que sea una verdad necesaria (ALCHOURRón y BULYGIN (2000) pp. 142 y 143, y BULYGIN (2001) pp. 436 y 437).

76 El problema que no capta la primera tesis, es que el razonamiento no discurre sobre la base de que estemos tratando con enunciados permisivos, sino que más bien con enunciados que confieren poderes privados, que tienen diferentes propiedades a los anteriores, y que exigen un razonar disímil. Vid., p. ej., ATIEnZa y Ruiz MANero (1996) pp. 45 y ss.
} 
estricto. De tal guisa, si no está prohibida una forma, no importa, porque esta vía formal debe estar contemplada en una regla o al menos posibilitada en relación con el principio específico que regula la institución ${ }^{77}$. Con ello se despeja la opción argumentativa que no apunte hacia las reglas del sistema registral y centra la argumentación en dicha regulación. Y esta forma de segunda inscripción no aparece prevista, ni posibilitada.

$2^{\circ}$ La tesis prescinde de manera absoluta del principio del buen orden registral. Este prescribe que todo registro debe ser llevado de manera que permita el conocimiento con precisión de lo registrado y el desenvolvimiento cierto de determinados aspectos del tráfico jurídico. Lo que se está discutiendo aquí no es la duplicidad de registros iguales, sino que de dos inscripciones que se superponen respecto de la misma situación, el nacimiento de una persona. Los registros buscan dar seguridades a las expectativas de los ciudadanos, para lo cual realizan sus actos de conservación al consignar los actos, estados o derechos. Ahora bien, para que exista la estabilización particular a las expectativas, es indispensable que no sean equívocos los registros, en el sentido de que pueda ser más de uno el registro sobre una única situación así considerada, con la consecuencia de que puedan darse diferencias entre uno y otro registro. Todo ello se evita con la univocidad del registro, es decir, una sola voz da cuenta de la situación. Tal bien jurídico, es uno de los subprincipios sobre los que se construye la institución de los registros civiles. Y ello se busca proteger por la ley cuando se dispone para el Registro Civil, que cualquier alteración o modificación solo puede ser realizada en virtud de sentencia judicial (art. 17 inc. 1 LRC.). Con dicha resolución se procede a realizar otra inscripción modificatoria -sea cambiándola o cancelándola-, tomándose razón de ella al margen de la partida.

$3^{\circ}$ Tampoco tiene en consideración el objeto del registro. A diferencia del Conservador de Bienes Raíces, que tiene por objeto las transferencias, permitiendo y regulando las diversas inscripciones sucesivas sobre un bien, el Registro Civil en materia de inscripción de nacimiento solo da cuenta de la existencia legal de la persona, la que se obtiene mediante el nacimiento ${ }^{78}$. De ahí que el buen orden imponga que a una persona, una sola inscripción de nacimiento.

$4^{\circ}$ La tesis acarrearía favorecer el fraude a la ley, con la no aplicación de la ley por sobre la norma de la alteración de la inscripción por vía judicial. Tenemos una disposición imperativa compuesta por una prohibición de alterar o modificar, en razón de los bienes jurídicos indicados, seguridad y univocidad. Si comparamos las dos inscripciones,

77 En materia de Derecho Civil, la calificación de una figura como de "Derecho estricto" es "menos estricta" que en otras materias, como el Derecho Penal. Así, p. ej., se entiende por los civilistas que el principio nemo auditur, el cual solo está contemplado en secciones específicas del Derecho ( $v . g r$. art. 1683) tiene vigencia general (Domínguez Benavente (1969) pp. 138 y 139). Pero ello ocurre también en el Derecho de los EE.UU., como en el famoso caso Riggs vs. Palmer, en el cual, en materia sucesoria, un pariente asesina a su causante testamentario para sucederle como heredero, sin que exista causal de indignidad contemplada en una norma. Un tribunal de New York sentenció que no obstante la legislación testamentaria y el testamento le dispusiese la herencia al asesino, se oblitera la operatividad de ellas mediante el principio de que nadie podía beneficiarse de su propio delito (DWORKIN (1989) pp. 73 a 82). Finalmente, en Alemania se considera que la exceptio doli es de alcance general, vía regla de principio general y no exige una previsión expresa de tal carácter (WACKE (1994) pp. 979 a 981, GALGANO (1992) p. 419).

${ }^{78}$ FUEYO (1982) p. 31. 
una sin reconocimiento y otra con reconocimiento paterno, es claro que una de ellas contiene algo que la otra no posee: el reconocimiento. Tanto el art. 31 no 4 LRC., como el art. 32 LRC., señalan que deben recogerse los nombres de los padres en las partidas, si la primera no las tiene y la segunda sí, entonces claramente hay una diferencia entre una y otra, y si la segunda tiene el reconocimiento, entonces está haciendo más cosas jurídicas que la primera, y, por tanto, alterando el contenido jurídico de la primera, cayendo así en la prohibición del art. 17 LRC. Para saltarse la prohibición del art. 17 LRC., no sería necesario una modificación o corrección, sino solo hacer una nueva inscripción correctora de las fallas. Pero si la tesis sostiene ello, hace inaplicable la prohibición en los casos particulares, volviendo disponible la norma imperativa, al recurrir a otra forma que la legal especial, y va en contra del propio principio rector de univocidad, cayendo en una contradicción con los principios que gobiernan la regulación de las inscripciones ${ }^{79}$.

$5^{\circ}$ Tampoco se ajusta la primera tesis a que la Ley del Registro Civil, tomando en consideración al buen orden registral, establezca especialmente la opción de alterar la inscripción en materia de reconocimiento. El Director puede modificar la inscripción de nacimiento, pero solo para efectos de que el hijo, previamente reconocido, pueda tener el apellido de los padres. Así, el art. 17 inc. 3 LRC., dispone: "Asimismo, el Director podrá ordenar, de oficio o a petición de parte, la rectificación de una inscripción en que aparezca subinscrito el reconocimiento de un hijo..., con el solo objeto de asignar al inscrito el o los apellidos que le correspondan y los nombres y apellidos del padre, madre o ambos”. Si se pudiese simplemente modificar ello con otra inscripción, entonces esta norma carecería de razón que la justifique.

60 Finalmente, el Derecho establece otras vías o poderes especiales para poder realizar el reconocimiento de manera simple para favorecer la filiación, sin tener que sacrificar el orden registral, como se puede ver en el propio artículo 187, en los números $2^{\circ}$ a $4^{\circ}$.

Es por todo ello que no es razonable sostener que se puedan realizar más inscripciones a discreción, sino una sola, y que cualquier alteración, corrección o modificación deba hacerse como manda el art. 17 LRC., por sentencia judicial, so pena de nulidad por desviarse de la formalidad prescrita por la ley. Y ahí volvemos al mismo punto en que nos encontramos: solo puede modificarse la inscripción en lo que diga la sentencia, y no puede aprovecharse la oportunidad de modificación, para reconocer en la modificación que se ordene. En cuanto al Registro Civil, este no puede permitir una nueva inscripción sin la sentencia que lo ordene.

\section{a.2. Escritura pública: (art. $\left.187 n^{\circ} 3\right)$}

\footnotetext{
79 SAlvador, AZAgra y FERnÁndez (2004) pp. 11 a 14, ponen el acento en dos circunstancias para el fraude a la ley: el sentido de la ley debe ser interpretado de forma teleológica y que esta figura encuentra su nicho en las normas imperativas y prohibitivas.
} 


\section{a.3. Acta ad hoc extendida en cualquier tiempo ante el oficial del Registro} Civil (art. $187 n^{\circ}$ 2), o en el acta del matrimonio (art. 37 LRC.)

En ambas situaciones las declaraciones ocurren ante el oficial del Registro Civil, la diferencia que se da en una o en otra es de tiempo, la primera, se da en cualquier momento, mientras que la otra es en el acto del matrimonio. Sin embargo, respecto del segundo tipo de caso es necesario revisar en vista de la nueva Ley de Matrimonio Civil.

En verdad, esta situación es procedente antes de sucederse a la inscripción del matrimonio mismo. Y se ve complementado con la orden legal de que el oficial del Registro Civil consulte privadamente a los contrayentes, por la posibilidad de reconocer hijos que ambos tengan en común: "El oficial del Registro Civil no procederá a la inscripción del matrimonio sin haber manifestado privadamente a los contrayentes que pueden reconocer los hijos comunes nacidos antes del matrimonio, para los efectos de lo dispuesto en el artículo siguiente" (art. 37 LRC.).

A ello debe agregarse la cuestión del matrimonio religioso. En la celebración ante ministro de culto no cabe esta posibilidad, ya que se trata de una situación puramente civil y, como indica la ley, ante oficial civil (art. 37 LRC.). El momento apto para proceder a ella, es aquel en que los contrayentes deben reiterar su consentimiento ante el oficial del Registro Civil -previo matrimonio religioso-, en el trámite para tener a la pareja como casados (art. 20 inc. 3 LMC.) ${ }^{80}$. Y ello, como se dijo, antes de proceder a la inscripción del matrimonio (art. 37 LRC.).

\section{b) Reconocimiento por acto mortis causa: Testamento (art. $187 n^{\circ} 4$ y art. 189 inc. 2)}

El testamento se trata de un negocio solemne, que no necesariamente consta en un instrumento público. Este beneficio para la forma testamentaria, está fundamentada en el respeto a la última voluntad que le dispensa la legislación civil. Se une a ello, la razón de facilitar la constitución del estado filial, pues la primera razón está enmarcada en las finalidades de orden público del Derecho de la Filiación. De esta manera, la autonomía cobra un sentido o alcance diverso bajo este contexto, subordinándose a la institución de la filiación, teniendo límites distintos a la del sistema sucesorio ${ }^{81}$. De esta guisa, el Derecho intenta darle valor a la última voluntad, dándole una mayor flexibilidad a las formas por las cuales esta deba evacuarse.

${ }^{80}$ El matrimonio religioso en Chile sigue, en la nueva ley, más o menos el mismo régimen que el ordenamiento antiguo. Así, sigue vigente el plazo para proceder a la ceremonia civil dentro de 8 días. Porque si no se realiza dentro del plazo no tiene ningún valor. Asimismo, una vez realizado el trámite ante el oficial civil, no se producen las consecuencias jurídicas retroactivamente desde el momento del matrimonio religioso, sino in actum desde el civil. De allí que no habría ratificación, que es retroactiva, según el Código Civil. Y, finalmente, la nulidad del matrimonio religioso no anula el estado de casado civil, es decir, aunque no haya matrimonio (religioso). De allí que se ha concluido que el matrimonio religioso no tiene mayores consecuencias civiles. (Así, Carlos Salinas A. en conferencia publicada posteriormente en (2006) pp. 49 a 100.

${ }^{81}$ En otras palabras, la capacidad de sopesar razones, respecto de la suerte que corra su propiedad, después de los días del causante, esto es, una materia que mira al interés individual de forma preferente, no alcanza a cubrir la situación de la filiación, en donde los sujetos afectados no están bajo la esfera de su dominio o servidumbre en las relaciones personales. 
Por su parte, debe tratarse de un testamento escrito y no testamento privilegiado de tipo verbal que regula el art. 1033, art. 1046 y art. 1056. La Ley del Registro Civil corrobora la idea de que sea un instrumento en que se otorgue (art. $6 \mathrm{n}^{\circ} 1$, art. 8). La ley, en el art. 213, parece hacer una restricción del testamento, al señalar en el inciso $2^{\circ}$ que el padre hubiere reconocido al hijo como suyo "en su testamento o en otro instrumento público".

Una cuestión sobre la cual pueden surgir dudas, es acerca del valor del reconocimiento cuando el acto testamentario solo contiene al acto de admisión:

Tesis negativa: No es válido porque desconfigura el testamento. El testamento es un negocio, esto es, una norma y el reconocimiento es un acto jurídico; al faltar las disposiciones y solo contenerse declaraciones, se desconfigura el negocio pretendido, esto es, el negocio testamentario. Igualmente, el testamento es un negocio mortis causa y el reconocimiento inter vivos, que se contendrían en un negocio mortis causa inexistente. Sin contenido disposicional no hay testamento, por lo que no se podría aplicar ninguna norma que suponga la operatividad de la formalidad de dicho negocio, es decir, que contenga la condición 'siempre que haya un testamento, entonces...'.

Tesis positiva: Sí tendría valor el reconocimiento. La ley atiende a las formas que revisten al negocio testamento, más que a la idea del negocio mismo, y a la declaración de última voluntad. Ello queda corroborado por la situación en que el testador puede haber revocado su testamento por completo, que contenía la declaración. Dado que si lo revoca, el negocio pierde validez (existencia), lo único que podrá subsistir es la declaración en el testamento de acuerdo al art. 189 inc. 2: "el reconocimiento es irrevocable, aunque se contenga en un testamento revocado por otro acto testamentario posterior...”. Es decir, en el negocio solo se contendría válidamente la declaración de reconocimiento, circunstancia que precisamente es permitida por el legislador, y además, se mantendría como válida la forma testamentaria para este solo efecto.

\section{c) Admisión en vía judicial (art. 199 bis inc. 1) (22 $^{82}$}

Estas materias de filiación no quedan, por regla general, al arbitrio de los particulares. Por lo que, no obstante exista acuerdo de voluntades, no se puede reemplazar la necesidad de la sentencia, por definición. En materia de reconocimiento, la ley establece una excepción para facilitar la constitución del estado filial. El acto de reconocimiento se realiza dentro de un proceso jurisdiccional y constituye una excepción al orden público filial. Quien sea demandado de reclamación, puede efectuar el reconocimiento a propósito de dicho proceso. No obstante, tanto el juez como las partes no han perder de vista que no se trata técnicamente de un allanamiento -que no excluye la sentencia y es inadmisible por el orden público-, sino que, derechamente, de un acto de reconocimiento, autónomo del proceso, sometido a su propia estructura y características. Y lo

\footnotetext{
${ }^{82}$ No obstante que la ley del art. 199 bis habla de "reconocimiento judicial" para esta clase de casos, en verdad ello no es así. Solo constituye una indebida economía de vocablos. En efecto, pues el factor reconocimiento jamás es judicial, sino que solo se da a propósito de un proceso judicial, sin perder autonomía la figura, es por ello que es mejor referir a esta situación como reconocimiento "en vía judicial”.
} 
mismo puede decirse de la conciliación, improcedente en materias de orden público, el que no permite la transacción en materias de estado civil (art. 2450) ni la mediación (art. 104 LTF.) ${ }^{83}$.

En tal sentido, no es necesario llegar a la sentencia, no porque se trate de un allanamiento o de una conciliación, sino porque ha actuado otro mecanismo y figura: la operatividad excluyente de los factores ${ }^{84}$. En efecto, al producirse el reconocimiento en la audiencia, la ley atribuye el estado filial directamente, lo que excluye la posibilidad de operar del factor de determinación "sentencia" 85 . Estando constituido el estado, a causa del principio de economía procesal no se sigue tramitando un proceso ya inútil.

Cuál es la razón de esta vía. Ella se encuentra en un camino intermedio entre lo que son: a) las formas no judiciales del reconocimiento, y b) la vía jurisdiccional de reclamación de la paternidad. a) En lo que nos interesa, la facilidad o expedición de la primera va de la mano con la expedita disposición de voluntad del padre para reconocer, sea como sea, que ella se logre (aunque se halle presionado por ciertas circunstancias, como de temor reverencial). En la situación fáctica para la admisión, no hay problemas en la voluntad del padre que obstaculicen la producción del acto. Es decir, el padre o la madre, tiene la disposición de ánimo para ir a la notaría o al Registro Civil y admitir su paternidad. b) La segunda situación es una vía construida especialmente -aunque no exclusivamente- para las circunstancias en que derechamente no ha habido voluntad de reconocer, por lo que demanda del Estado la constitución del estado filial respecto del padre renuente.

La vía del reconocimiento a propósito de un proceso, al encontrarse a medio camino, si bien supone una voluntad libre para reconocer, cuando así ocurriese, también supone una disposición de ánimo no expedita para el reconocimiento. En tal sentido, esta figura tiene como ratio legis, la posibilidad de que un supuesto padre o madre no tenga la disposición de ánimo de reconocer de forma espontánea. De tal manera que no le interesa ir, p. ej., a una notaría a reconocer por escritura pública. Así que se crea un sistema más simple que la sentencia jurisdiccional, mediante la cual, usando de las formas judiciales, se cita al supuesto padre a la audiencia preparatoria del juicio, para que declare ante el Estado, representado por el juez, su creencia sobre la progenitura. Y esta es una medida razonable, pues en todo orden jurídico hay una mayoría de ciudadanos que prestan adhesión al ordenamiento estatal de manera más o menos voluntaria. Por ello que esta vía se basa en el respeto de los ciudadanos por la honestidad y veraci-

${ }^{83}$ En base a estas razones, mantiene su vigencia la tesis sostenida en sentencia de 3 de abril de 2003 de la Corte Suprema, de redacción del juez Eleodoro Ortiz (sala civil) que corrigió de oficio por el art. 84 del CPC., la resolución de la Corte de Rancagua la que, a su vez, había casado de oficio la sentencia de primera por no haber llamado a conciliación: " $5 \circ$... tratándose de un juicio de filiación, materia en la que no es procedente la transacción puesto que, precisamente, versa sobre el estado civil de las personas, no corresponde el llamamiento de las partes a conciliación; $6^{\circ}$.- Que, habiéndose dispuesto la práctica de una diligencia no procedente en este tipo de materias, es nula la resolución dictada en este sentido" (caso "Benavides Espinoza con Zúñiga Conejera", rol 2903-03, en www.lexisnexis.cl, no identificador 26345).

${ }^{84}$ GANDUlFo (2006) pp. 86 y ss.

85 Por esta misma razón no se requiere de una resolución especial de "téngase por reconocido" por parte del tribunal. El acto de la parte declarante es suficiente. 
dad en las declaraciones prestadas ante las magistraturas jurisdiccionales. Y además le sirve al reconociente evitarse las eventuales costas y costos de un proceso completo de paternidad. De ahí que sea de utilidad frente a un padre o madre renuente a reconocer, pero que sea susceptible a la presión del enfrentamiento ante el órgano judicial, y así evitar un largo tiempo en un proceso de reclamación; de tal manera que, mediante esta forma, también se sirve a la simplificación de la constitución del estado filial.

Agente provocador. Quien genera la vía en sede judicial, es solo el que tiene legitimación activa para demandar de reclamación de estado filial, según las reglas generales.

El problema del mandatario. Dos posiciones se pueden sostener aquí. La negativa a la presencia se funda en que, por la propia ratio legis de existencia de esta gestión y el carácter personalísimo de la filiación, se apunta a la presencia personal del demandado de reclamación (sin perjuicio de que la ley no establezca consecuencias coactivas a la ausencia). Refuerza la idea de la presentación personal la Ley de Tribunales de Familia, que establece el deber de comparecer personalmente a los intervinientes (art. 60 LTF.) ${ }^{86}$-salvo casos excepcionales-.

Por otra parte, se puede analizar en pro de la aceptación del mandatario, con relación a las actitudes de quien deba someterse a esta gestión, la siguiente distinción. Respecto de la voluntad positiva del mandante, bien se puede actuar mediante mandato especial para esta gestión, con tal de que se tomen las providencias necesarias para satisfacer las exigencias del bien protegido por la calificación de "personalísima”. En tal sentido, si la ley pretende que el interesado esté necesariamente involucrado en los resultados de las gestiones que lo puedan afectar, entonces este puede participar, diputando a alguien para que cumpla específicamente su voluntad en las gestiones particulares. De ahí que pueda realizarlo mediante abogado, si es que lo diputa mediante mandato judicial, especialmente facultado para esta gestión particular, con todas las limitaciones que jurídicamente quiera ponerle; de hecho, la ley contempla esta forma de participación en juicio en el art. 6 no 2 CPC. La ley de Tribunales de Familia permitiría excepcionalmente esta opción, al facultar al juez para que eximir a la parte de comparecer personalmente, lo que deberá hacer por resolución fundada, según el inc. 2 art. 60 LTF. Respecto de la decisión negativa del mandante, la ley precisamente busca la presencia personal. No obstante, al faltar el mecanismo de coerción, da lo mismo que se lleve un mandato específico con la orden de rechazo o que se considere inválido el mandato, $y$, por ende, ausente en la audiencia, pues en ambos casos el art. 199 bis contempla que se ordene de inmediato las pericias biológicas.

De réplica se podría volver a traer a la palestra la discusión de la inutilidad de la posibilidad de contar con mandatario para reconocer, pues para realizar la diputación, están dadas todas las condiciones para que realice directamente el mandante la admisión de paternidad. Por ello el mandatario, en este caso, solo podría servir para obviar el

\footnotetext{
${ }^{86}$ Antes de la reforma de la Ley 20.030, RAMOs (2001) no 514, p. 392, sostenía que quedaba excluido el representante convencional de concurrir en la gestión de citación judicial a admitir la paternidad. La razón formal estaba en que la ley exigía expresamente la comparecencia personal del citado. Así, el derogado inc. 2 parte $2^{a}$ art. 188 enunciaba que "se requerirá la presencia personal del supuesto padre o madre". En similar sentido, VELOSO (2000) p. 118; y CORRAL (1999) p. 60.
} 
enfrentarse con el tribunal y con el demandante (situación que no ocurre cuando hay disposición de ánimo en reconocer de manera espontánea), perdiéndose el objetivo funcional de esta gestión ad hoc. Al ir en contra de tal fundamento, se oblitera la justificación de la interpretación positiva.

Oportunidad en que se puede producir: Según vimos, para efectos de facilitar la constitución del estado filial, la ley unificó los procedimientos de: a) gestión judicial ad hoc de reconocimiento, y b) el de constitución de estado por sentencia jurisdiccional. Ello se tradujo en que la ley incorporó un momento especial, para posibilitar el llevar a cabo este acto de reconocimiento, a propósito del proceso de reclamación de estado: la "audiencia preparatoria" que regula el art. 61 LTF. Así, la Comisión Mixta en el Congreso, expresó oficialmente, dentro de los objetivos de la reforma a la filiación: "Permitir que se ordenen judicialmente los exámenes de ADN durante el procedimiento dispuesto para las acciones de reclamación, en aquellos casos en que la persona citada no comparezca a la audiencia preparatoria, o bien, manifieste dudas al respecto" 87 .

Previo a la contestación se debe realizar el acto solemne de reconocimiento de paternidad o maternidad. Si preguntado allí por el tribunal, acerca de la posibilidad de reconocimiento, la parte demandada reconoce, entonces se constituye el factor y puede la ley atribuir el estado filial (art. 199 bis). Por este mismo carácter excepcional, si ocurre en cualquier otro momento procesal no autorizado por la ley, el acto tendrá vicio formal que afecte su valor. Fuera de dicho momento procesal, el ministro de fe carece de poderes para autorizar el acta.

Actitudes que puede adoptar el demandado:

i. No comparece: No hay imputación de consecuencia legal directa para la constitución del estado.

La razón de ello está en el principio jurídico de verdad biológica, que prescribe: es necesario que exista una relación entre la atribución formal del vínculo filial y lo que podríamos llamar la cuestión de fondo, como es el suceso de la procreación natural. Y eso por la conexión que tiene con el principio de identidad, el niño no tiene derecho a un padre cualquiera, sino a su padre biológico, de acuerdo con el art. $7 \mathrm{n}^{\circ} 1$ y art. $8 \mathrm{n}^{\circ} 1$ ambos de la CDN. ${ }^{88}$. Ahora bien, la faz negativa de la variante de regla de juicio de nuestro principio verdad biológica, dispone "que no se establezca la filiación por solo una herramienta jurídica, esto es, mediante el mero mecanismo legal de atribución de la calidad de hijo, padre o madre, ligándola a uno o varios actos o abstenciones que no tengan una relación con la corroboración de la realidad biológica filial' 89 . En nuestro caso, no

\footnotetext{
${ }^{87}$ Informe de la Comisión Mixta, Boletín 3.043-07, a la ley 20.030. La abogada del Sernam, Carolina Espinoza, en la Comisión Mixta "explicó que el nuevo artículo apunta a que, deducida la acción de reclamación de filiación, si el demandado en la audiencia preparatoria -trámite consagrado en la ley No 19.968, que crea los Tribunales de Familia- reconoce su paternidad, el procedimiento termina; y si no comparece, o niega o manifiesta dudas acerca de su paternidad, el juez ordenará la práctica de la prueba de ADN".

${ }^{88} \mathrm{El}$ art. 7 de la Convención de Derechos del Niño dispone que: "El niño... tendrá derecho desde que nace a un nombre... y en la medida de lo posible, a conocer a sus padres y a ser cuidado por ellos". Mientras que el art. 8 indica: "Los Estados Partes se comprometen a respetar el derecho del niño a preservar su identidad...".

89 GANDULFO (2006) pp. 77 a 82; vid. también GANDULFO (2005b) pp. 14 y 15.
} 
importa cuántas veces haya sido citado, la propia notificación no tiene una relación directa con los sucesos de la procreación o el acto sexual, sino solo con el acto formal de admisión. Y no existe una relación simétrica entre el reconocimiento y la ausencia a la práctica de la gestión reconocimiento, puesto que la primera está basada en la autonomía moral de los individuos, y la segunda solo en facilitar el uso de dicha autonomía. Si la ley dispusiese lo contrario o se interpretase en contra de la relación indicada, no habría siquiera una garantía al derecho a la identidad del niño a través de la verdad biológica, por lo que pasarían a ser inconstitucional en virtud de lo dispuesto por la Convención de Derechos del Niño en relación con el art. $5^{\circ}$ inc. 2 de la Constitución. Finalmente, no hay mayores consecuencias como la atribución del derecho de alimentos, como lo había en la legislación anterior, ya que no hay ninguna relación jurídica en que se pudiese basar los alimentos ${ }^{90}$.

Lo que dispone el Código Civil es que en tal evento, el juez ordenará de inmediato, es decir, en la misma audiencia preparatoria, pero en su fase que indica el art. $61 \mathrm{n}^{\mathrm{o}}$ 8 LTF. (de ofrecimiento y disposición de medios), la práctica de pericias biológicas de acuerdo con el art. 199 bis inc. 1.

ii. Concurre: Puede devenir en dos alternativas si concurrencia:

a) No reconoce: La ley configura el reconocimiento como un acto jurídico, por lo que se necesita la declaración de voluntad. El no reconocimiento puede adoptar dos formas:

1) Niega: Sea en la primera o segunda citación a la audiencia preparatoria, no hay admisión de paternidad, ni, por tanto, atribución legal de filiación, poniendo fin a la oportunidad sin consecuencias legales. A quien demande solo le quedará seguir con la tramitación jurisdiccional.

2) Responde con evasivas o dudas. Dado que no se trata de una confesión, sino de un acto jurídico de admisión, no corresponde que ante las repuestas evasivas se declare como admitido. Todo acto de reconocimiento en la nueva legislación filial está configurado como un acto jurídico que realiza el reconociente, por tanto, es voluntario. De ahí que si es voluntario, no puede ser forzado estimando el tribunal que hay reconocimiento en contra o en ausencia de voluntad del pretendido padre. Si la voluntad no está manifestada, no hay voluntad jurídicamente relevante de admitir. Por ende, no es aplicable la solución de la confesión ficticia de los procesos jurisdiccionales o también llamados "contenciosos" (como indica, por ejemplo, el art. 394 CPC.).

En ambos casos, la ley dispone en el art. 199 bis inc. 1, que el juez ordene en la audiencia preparatoria, la práctica de la pericia biológica al demandado (art. 61 no 8 LTF.), cuyo resultado deberá ser presentado en la audiencia de juicio.

b) Reconoce: Como indica la regla en materia de reconocimiento, se necesita la manifestación de voluntad de admitir. El acto de contestación no es una formalidad que

\footnotetext{
${ }^{90}$ La antigua legislación sí contemplaba la posibilidad de establecer alimentos, cuando no asistía el citado. El antiguo sistema era bastante rígido y limitativo en materia de investigación de paternidad, por lo que era bastante razonable suponer que las acciones de reclamación no eran de fácil acogimiento. En ese contexto, parecía razonable entregar un paliativo a la rigidez imperante. Sin embargo, esa no es la situación del actual del sistema legal, por lo que no hay ninguna razón para establecer semejante medida en el nuevo ordenamiento filial.
} 
pertenezca al reconocimiento, lo que muestra que no estamos ante un mero allanamiento. Ahora bien, el rasgo oral del procedimiento hace que el registro de audio sea el único válido, en general ${ }^{11}$. No obstante, dada la especial exigencia del Código Civil, la voluntad de admisión debe quedar contenida en una acta ad hoc. De tal guisa, el art. 199 bis inc. 2 dispone especialmente: "El reconocimiento judicial de la paternidad o maternidad se reducirá a acta" 92 . Tal acta debe ser firmada por el juez y el ministro de fe del juzgado, quien la autoriza $^{93}$ (pues debe remitirse copia auténtica del acta al Registro Civil). Pero, por influencia del rasgo oral de las normas de familia, dicha acta no va firmada por el reconociente, quedando constancia auténtica suficiente -en su reemplazo- en el registro de audio de la audiencia, que complementa así el acta como solemnidad. El tribunal de oficio debe remitir dicha acta al Registro Civil (inc. 2 art. 199 bis), para dar cumplimiento a la subinscripción del art. 6 LRC., adjuntándose a aquella, según se ha determinado en la práctica, el registro del audio.

La necesidad de juramento ya no constituye solemnidad, pues fue eliminada por la ley 20.030 .

\subsection{FORMALIDADES DE PUBLICIDAD Y DE PRUEBA}

Bajo la presidencia de la idea de protección a las expectativas estabilizadas por el Derecho, se erige la necesidad de la mantención en situaciones de seguridad y previsibilidad para los ciudadanos respecto de sus negocios, derechos y situaciones que se den en particular en la vida jurídica. Ellos en muchas circunstancias constituirán los supuestos o incluso las normativas por las que deberán regir y prever la dirección de sus destinos ${ }^{94}$. Para cumplir dicho fin se erigen los registros en el Derecho Privado, los que -como indica F. Fueyo- no tienen solo por función simplemente dejar una constancia de ciertas circunstancias, en el sentido de conservar algo. Los registros, además, tienen la función de divulgar a la población aquellas circunstancias que han quedado registradas. "De no existir esa publicación, para conocimiento actual o eventual de todos, en cuanto a tan variados contenidos, el registro se menoscaba notablemente, se desvirtúa o deja de servir y ser" 95 . Es bien reconocido que el estado filial tiene un amplio espectro de acción, que afecta a muchas más personas de las que él involucra. Es por esta razón que la ley exige que los factores a los cuales la ley les atribuya el estado filial, especialmente, el factor

91 De acuerdo al Manual de "Procedimientos para Juzgados de Familia", de la Corporación Administrativa del Poder Judicial, de julio del 2006, se contempla en su punto 3.9: "En razón de su fidelidad y eficiencia, se hará uso exclusivo del sistema de registro de audio para las audiencias realizadas ante el Juez de Familia. Este registro será el único válido".

92 En sentido similar en el antiguo sistema ABELIUK (2000) no 61, p. 91.

93 La participación del Administrador del tribunal viene determinada por el art. 118 LTF. en relación con el art. 389-g COT. No obstante, por decreto económico del Tribunal de Familia tal potestad es en la práctica delegada en otros funcionarios del juzgado.

94 Como señala RAWLS en (1995) pp. 173 y 174, esto supone nuestra calidad de agentes racionales, en cuanto somos capaces de construir planes de vida, tomando en cuenta expectativas razonables, respecto de necesidades y exigencias futuras, hasta donde puedan preverse, a partir de su posición en la sociedad y las condiciones normales de la vida humana.

95 Fueyo (1982) p. 197. 
reconocimiento, deban constar en estos registros públicos que dan cuenta de la existencia de los individuos: el "libro de nacimientos", pertenecientes al Registro Civil (art. 2 no 1 LRC.).

En materia de reconocimiento, dependiendo de la solemnidad que se use para constituir el factor reconocimiento, habrá que determinar la forma de la publicidad.

1) Hay una sola solemnidad que constituye a la vez una forma de publicidad. Esta es la solemnidad que se constituye dentro de los propios registros del Registro Civil: reconocimiento en la inscripción de nacimiento.

2) Las otras formas que no constan en el propio registro de nacimiento deben subinscribirse al margen de la respectiva partida o inscripción de nacimiento (art. 187 inc. 3, art. 189 inc. 3, art. 199 bis inc. 2, art. 6 no 1 LRC. y art. 8 LRC.).

Problema especial del testamento:

Tesis negativa: El testamento se trata de un negocio o acto, configurado especialmente para la última voluntad; es decir, para que la última voluntad de una persona pueda construir un cierto régimen jurídico, para después de los días de su vida, de allí su denominación como mortis causa. En consonancia con ello, la ley prescribe que el testamento solo entra en vigencia después de la vida de quien lo otorga, según lo indica el art. 999. Por ende, no puede inscribirse ni regir para terceros, antes de la muerte del testador. La legislación civil italiana contiene una disposición en concordancia con esta tesis: "Cuando está contenido en un testamento [el reconocimiento], tiene efecto desde el día de la muerte del testador”, según el art. 256 CC.it.

Tesis afirmativa: El testamento solo tiene total vigencia después de la muerte. Antes de ello, solo puede existir una atribución parcial de consecuencias. Así, el art. 186 dispone que la filiación quede legalmente determinada por el reconocimiento. Mientras que el inciso final del art. 181 dispone que la acreditación sea por los medios que establece el tit. XVII del estado civil. Finalmente, la ley dispone que no sea susceptible de modalidades el reconocimiento, según el inc. 2 del art. 189, a efectos de no afectar la consecuencia legal. Y ello debe abarcar la protección en contra de las personas que recurren al amparo de estas formas legales, por medio del tipo de acto mortis causa, para saltarse el impedimento legal de establecer la modalidad del plazo suspensivo y así burlar el régimen in actum establecido por la ley. La autonomía de la voluntad sigue siendo dirigida a la finalidad de orden público filial.

Tesis intermedia: De acuerdo con R. Abeliuk, habría que distinguir si es un testamento abierto o cerrado: el testamento cerrado jurídicamente solo puede abrirse después del fallecimiento, por lo que no tendría validez de testamento, si es que fuese violada su forma de cierre. El testamento abierto, sí podría, pues no le alcanzarían las razones antes expuestas, y sí estaría amparado por la justificación de la tesis afirmativa ${ }^{96}$.

\subsection{CONSECUENCIA POR FALTA U OMISIÓN DE FORMALIDADES}

7.3.1. Faltas objetivas: si se omite un instrumento o vía, establecidos por la ley, el acto no tendrá valor como tal acto típico para el Derecho. Esto significa que si, p. ej., la

${ }^{96}$ ABELIUK (2000) no 54, p. 83. 
declaración se emite por escritura privada inter vivos, este no se perfeccionará como tal reconocimiento, porque la ley exige que la declaración de voluntad se manifieste de determinada forma. Esto significa que no se activará el mecanismo de atribución del estado filial. Al carecer de valor ab initio, la declaración no estará protegida por el principio de conservación de los actos. Asimismo, ni el juez ni los funcionarios del Registro Civil pueden considerar como que hubiese reconocimiento, y, por tanto, deben negar la subinscripción. Siendo así las cosas, si se llegase a subinscribir, entonces cualquier circunstancia procesal deberá ventilarse vía una acción de mera certeza. Es bastante claro que no obstante que alguien pueda tener a su favor un documento como una escritura privada por más de diez años, no podrá sostener que ha prescrito la acción de nulidad en contra suya y que tiene consolidada su situación filial. De todas formas, puede servir como medio de acreditar la paternidad contra el padre que no insista en el reconocimiento.

De acuerdo a la tesis de la independencia de los actos, la nulidad del instrumento solemne no acarrea la nulidad del reconocimiento, en particular, cuando el instrumento tiene un doble carácter. Así, por ejemplo, si la inscripción de nacimiento de un menor, en la cual, además, se constituyó el reconocimiento, es anulada, este no se anularía, por tres razones: $1^{\circ}$ Porque las consecuencias jurídicas del mismo instrumento son distintas: una para acreditar la existencia legal de una persona y otra para determinar su filiación. $2^{\circ}$ Porque el reconocimiento y la inscripción son actos diferentes. $3^{\circ}$ Porque el estado de hijo se adquiere de forma definitiva e irrevocable, así como en el caso del testamento, en que este puede revocarse como instrumento permanece válido el reconocimiento. Por ello es que no hay contradicción entre sostener la nulidad de la inscripción y la validez del reconocimiento 97 .

Esta tesis creo que adolece de ciertos errores que afectan la conclusión final. Es cierto que el instrumento tiene un doble carácter, siendo dos actos distintos. Sin embargo, el soporte de ambos actos, la inscripción de nacimiento y el reconocimiento, es uno solo: la partida de nacimiento. Es esta conclusión la que justifica que, como en casos de reconocimiento, no se proceda a subinscribir el reconocimiento en la partida a pesar de ser dos actos distintos, pues la formalidad de publicidad se cumplió con un solo acto. Desde el punto de vista de la teoría de las formalidades, estas son las formas en que se expresa de manera válida la voluntad para el Derecho. Por lo tanto, a la suerte que corra el instrumento, se encuentra ligado el destino que tenga la manifestación de voluntad del reconocimiento así como su valor. De tal guisa, si se pierde el soporte completo, por circunstancias de alcance general, entonces la manifestación de voluntad de admisión pierde valor. Cuestión diferente es lo que ocurre en el evento de la revocación del testamento. En esta situación, dado que se trata de una convención revocatoria, la ley limita las consecuencias, cosa que no ocurre necesariamente así en la nulidad, pues como norma estatal se impone a prácticamente cualquier situación. La nulidad tiene consecuencias retroactivas, es decir, nunca pudo haberse realizado el reconocimiento por esta vía prohibida. Pero podría alegarse una división del documento, para salvar la nulidad

${ }^{97}$ Así, Corte Suprema, sentencia de 19 de mayo de 1958, RDJ., tomo 55 (1958), II, sección 1a, pp. 93 y 94. 
del reconocimiento. Sin embargo, el problema con ello es que si se alega una causa general que afecta a la solemnidad por completo, como en el caso de la segunda inscripción, esta barre con toda la solemnidad, perdiéndose para todo lo contenido en ella. A diferencia de la revocación testamentaria, en que el Derecho determina que el testamento en esa parte no sea revocable, es decir, el testamento aun subsiste; si no fuese así, entonces no tendríamos un argumento que sostuviese la subsistencia del reconocimiento, cuando falla el elemento solemnidad.

De esta manera, si se anula el instrumento que constituía la solemnidad, aunque contenga dos actos diferentes, entonces anula el reconocimiento, a lo que se puede llamar: tesis de unidad de la forma.

7.3.2. Faltas de publicidad y de prueba: si falta la subinscripción al margen de la inscripción de nacimiento, entonces el ordenamiento jurídico contempla dos clases de consecuencias:

i) Inoponibilidad. La configuración de esta sanción estriba en que la constitución del estado filial, requisito indispensable para que puedan gozar de ciertos derechos algunos y de privar de otros potenciales a diversas personas, ese supuesto, entonces no va a empecer a los derechos de terceros de buena fe "adquiridos antes de la subinscripción" (inc. 3 art. 189). La subinscripción no tendrá vigencia retroactiva en estos casos. Mirado desde la otra faz, la inoponibilidad no va a afectar a la situación previamente constituida a la filiación. Si no lo está, entonces rige plenamente el factor y el estado constituido.

ii) Inacreditabilidad. Esta consecuencia no es un óbice al supuesto de las normas civiles, sino que se configura como un impedimento de que determinados instrumentos puedan hacerse valer en un proceso jurisdiccional respecto de todos, de acuerdo con el art. $8^{\circ}$ LRC. Como ha prescrito la Corte Suprema, en vieja sentencia redactada por el juez Roberto Peragallo (la cual voy a parafrasear), esta norma dispone una consecuencia relativa a los juicios, y es en ellos en que no puede tomarse en cuenta el instrumento, p. ej., 'sentencia', que produce -o activa- el cambio de un estado. Siendo así las cosas, los jueces de la instancia deben, a falta de otro instrumento con aptitud legal para producir dicho cambio, considerar la situación fáctica en el estado en que se hallaba antes de dicha sentencia. En nuestro caso, sería sin tener por determinada la filiación. Todo esto es sin perjuicio de que tenga pleno valor respecto de los involucrados en la relación constituida e incluso respecto de terceros, bajo la condición de que sea fuera de un proceso jurisdiccional. La razón de todo ello está en que "la ley resguardando los intereses de terceras personas, ignorantes” de dichos instrumentos, las dispensa de toda vinculación jurídica consecuencial, que pueda derivarse de aquellos instrumentos. Y así, p. ej., en un juicio ejecutivo no podría obstaculizarse el procedimiento de realización, alegando una mutación de cambio de dominio de un bien, basado en las consecuencias filiales que la ley atribuiría en principio a un instrumento público de reconocimiento, en conjunción con el sistema sucesorio; es decir, dicho instrumento en un juicio ejecutivo particular no logra acreditar el cambio de dominio o de posesión.

Y a ello debe agregarse que, a la inscripción, el Derecho no le atribuye un régimen retroactivo al proceso. Por lo que una inscripción tardía, ya iniciado un proceso, se estima 
como inoperante respecto de este. De lo contrario sería sorprender a las expectativas estabilizadas de los terceros, y "nunca sería posible discernir acerca de [la] válida subsistencia [de un acto o negocio] y [de los] consiguientes resultados en el Derecho, expuestos como estarían a ser modificados por voluntad futura y exclusiva de una sola parte y aún de terceros". Por ello es que la ley diría que no puede hacerse valer en juicio, "sin que haya precedido la inscripción o subinscripción que corresponda"; o sea, según la ley la inscripción debe preceder al proceso, para hacerla valer en él. Finalmente, "la sanción misma establecida expresamente por el artículo $8^{\circ}$ para innumerables efectos de bien social y económico, carecería de toda eficacia, o mejor dicho, no podría ser cumplida, ya que estaría al arbitrio de la persona sancionada la operatividad retroactiva para hacer valer en juicio" el nuevo estado, "que la ley ordenó que no valiera [en juicio], sin inscripción precedente" 98 .

Creo que la tesis anterior debe ser bastante matizada. Así, debe distinguirse la situación de los derechos, respecto de la situación del estado filial.

En cuanto a los derechos, sostengo que la inscripción, al menos en materia filial, si tiene alcance retroactivo en el proceso: por la retroactividad de la filiación que ordena el art. 181 y por la operatividad excluyente de los factores, aunque ello hará más compleja la solución del caso de choque de factores habiendo previa inscripción del factor tardío. En efecto, una vez que queda configurado el factor en el caso particular, se atribuye el estado filial derechamente, y se retrotrae. Lo anterior está corroborado por el art. 181 inc. 1. Ahora bien, un factor de determinación según he sostenido, es una forma para lograr constituir un estado filial. Por lo que cuando queda constituido el estado, aun en virtud del reconocimiento, y en virtud del art. 181 inc. 1, el estado se retrotrae a la fecha de la concepción, esto es, antes de la demanda y de la sentencia, por lo que debería entenderse incorporado a la situación de la demanda.

No obstante, podría sostenerse que esa retroactividad estaría limitada solo para los procesos por el art. $8^{\circ}$ LRC., así como la limitación del art. 181 inc. 2 (y que, por lo demás, la nulidad también es retroactiva -caso original de la sentencia-). Pero esta tesis, desde el punto de vista de los derechos, si bien es cierto que no afecta la configuración de la idea de factor (porque el estado y los derechos se seguirían atribuyendo de acuerdo a la figura básica del hecho, acto o norma misma que constituye el factor, sin agregar como elemento a dicha noción el de inscripción o subinscripción, ya que no afecta fuera del proceso), no lo es menos que la tesis cercena en gran medida la configuración del mecanismo atribución del estado y sus derechos. Hacerlos valer en el proceso, constituye una de las circunstancias más importantes, pues los tribunales son las garantías de los derechos (y situaciones constituidas legítimamente). Sin retroactividad no habría garantía, y por operación de la autoridad de la cosa juzgada, al considerarse como si no hubiese reconocimiento, entonces en la práctica se perderían, con la autoridad de la

98 Fallo "Caja de Ahorros con Palma", de 16 de septiembre de 1942, y se refería al problema de la no inscripción de la nulidad de matrimonio en el Registro Civil, en el contexto de un juicio ejecutivo. RDJ., tomo 40 (1942), II, sección $1^{a}$, pp. 202 y ss. Para el agudo lector, no se puede dejar escapar un cierto estilo dworkiniano en el razonamiento del juez Peragallo, solo que este ocurrió más de 30 años antes de que viera la luz el paper: El Modelo de las Normas (I). 
sentencia, los derechos que le corresponderían a los involucrados en la filiación, ya no desde el punto de vista procesal, sino sustantivo o material. Y con ello se alteraría en gran medida el mecanismo de atribución de derechos del art. 181, aun respecto de los derechos sucesorios, que ordena la ley se adquieran retroactivamente, como contraexcepción del inc. 2 parte $2^{\mathrm{a}}$ art. 181, incluso por sobre los derechos adquiridos por terceros previos a la subinscripción. En la práctica, un particular derecho sucesorio no se tendría por constituido, exponiendo a perdérselo por quien no ha inscrito. $Y$, además, la función de limitación de adquisición de derechos retroactivamente, la efectúa directamente el Código Civil, sin eufemismos sobre el valor en el proceso, en el art. 181 inc. 2 parte $1^{\text {a }}$ : "No obstante subsistirán los derechos adquiridos y las obligaciones contraídas antes de su determinación". Por tanto, lo que está señalando el art. $8^{\circ}$ LRC. es que para "hacerse valer en juicio", significa que para que puedan influir en la sentencia, debe haberse procedido a la subinscripción, p. ej., del acto de reconocimiento antes de la sentencia.

En cuanto al estado filial, ocurren las consecuencias más graves, si le hacemos aplicable el art. $8^{\circ}$ LRC., porque afectaría a la operatividad excluyente de los factores de determinación y a la noción de factor de determinación. Así, p. ej., se tramita un proceso de reclamación de estado, en el cual se establece por sentencia que el padre de Roberto Nieto Nieto es Eric Romeral y, luego de ella, se realiza por otro, Manuel Spinoza, el reconocimiento de Roberto Nieto y lo inscribe antes de la sentencia. Entonces, se destruye el sistema de atribución de filiación, desconfigurando la figura del "factor" y el sistema de operatividad excluyente. Si lo llevamos a un proceso para discutir la situación ocurrida (vía acción de mera certeza, "negatoria"), entonces tendremos lo siguiente: La filiación -según este caso resuelto de acuerdo a la primera tesis-, no se entendería atribuida con la norma de la sentencia ni con el acto de reconocimiento, sino que con la subinscripción. El juez que le toque resolver este problema, si extiende el art. $8^{\circ}$ LRC. a estos casos de constitución de estado filial, entonces tendrá que razonar que, dado que le falta la inscripción a don R. Nieto, entonces debe considerársele como si no tuviera la filiación constituida, por lo que no se aplica el art. 189 y fue correcta la subinscripción. A don R. Nieto solo le quedará ejercer de nuevo la acción de reclamación (en conjunto con la de impugnación). Sin embargo, de acuerdo al ordenamiento civil don R. Nieto no necesita ejercer una acción constitutiva de reclamación. Le basta una acción de mera certeza, "negatoria" de la paternidad de Manuel Spinoza y, en su consecuencia, que se cancele la subinscripción y nada más. La tesis extensiva termina desconfigurando la figura del factor, pues con la sentencia que desestima la acción "negatoria", queda como padre el que constituyó segundo su factor. Lo que solo es justificable en la sentencia porque: a) o bien todo factor de determinación supone en su configuración la subinscripción, es decir, que cuando se define lo que sea un factor, debe agregarse la subinscripción, es decir, una definición más compleja, b) o bien, porque no hay operatividad excluyente de factores; ambas situaciones son inadmisibles, porque la versión "a)" va en contra del supuesto mismo de que partimos, el art. $8^{\circ}$ LRC. solo trata de una sanción de no poder acreditar en juicio, mas no de orden sustantivo, mientras que " $b$ )" va en contra de la regla de que no hay reconocimiento ipso iure, cuando se ha constituido filiación distinta previamente, como prescribe el art. 189 inc. 1. 
Los factores de determinación, en la teoría de factores, están identificados solo como tales: los hechos, actos o normas, p. ej., el reconocimiento o la sentencia, pero no la subinscripción. Y son dichos hechos -en sentido amplio- de definición simple, a los que se les atribuyen luego la constitución del estado. Y esto en razón de que existe otra sanción ante la falta de subinscripción, como la inoponibilidad, que sería totalmente absurda su prescripción, si es que no se le atribuyese luego el estado filial a tales circunstancias definidas en términos simples. Si fuese atribuido el estado al factor en sentido complejo, no existiría la norma de inoponibilidad del art. 189 inc. 3, porque no habría filiación válida que siquiera intentar oponer.

Ahora bien, si se sostiene que la definición de factor de determinación filial es en términos simples, entonces debe sostenerse que no hay operatividad excluyente del primer factor que se constituyó. Ello porque en el proceso de acción "negatoria” y su sentencia definitiva, tendría que acogerse el reconocimiento secundario, subinscrito de forma primaria. Pero aquí ya sería muy problemático, pues sostener que hay un factor de determinación totalmente válido, es sostener que se le atribuye el estado filial, y, en tal caso, se estaría yendo en contra del art. 189 inc. 1 ("No surtirá efectos el reconocimiento de un hijo que tenga determinada una filiación distinta"). Precisamente, la tesis extensiva le estaría dando pleno valor al reconocimiento en contra de filiación distinta, superponiéndose filiaciones que son incompatibles como la de estos dos padres ${ }^{99}$.

En conclusión, la sanción de inacreditabilidad del art. $8^{\circ}$ LRC. no tiene alcance sobre disputas que tengan que ver con la constitución del estado filial mismo. Solo tiene dominio sobre los casos en que se disputen los derechos emanados de la filiación, y en esta disputa sí tiene alcance retroactivo acompañar la subinscripción.

La diferencia entre las sanciones de inoponibilidad y de inacreditabilidad está en que la primera impide hacer ejecutar los derechos y obligaciones a terceros, mientras que la segunda impide hacer valer los derechos y obligaciones respecto de terceros y de las partes mismas de la relación invocada, en los procesos jurisdiccionales.

\section{FORMAS DE DEJARLO SIN VALOR}

I. a) Repudiación, y b) la Nulidad del acto. En cuanto a la segunda, la nulidad del acto. Ella es directa, en razón de que la pretensión de la acción de nulidad estriba directamente en dejar sin valor el acto de admisión, mediante vía jurisdiccional, atacando el procedimiento de construcción o manifestación de la voluntad, pero sin discutir la verdad de la relación biológica. Igual sentido tiene la repudiación, solo que ello lo logra

${ }^{99}$ Es por ello que creo que la judicatura correctamente resolvió el caso en que una mujer ejerció acción de reclamación filial por su hija, y estando ya iniciado dicho proceso, citó, aparte, al supuesto padre a la gestión judicial ad hoc de reconocimiento, en la cual reconoció a la hija. Luego, se presentó al proceso jurisdiccional el reconocimiento. La Corte de Apelaciones de Concepción, en fallo de redacción de Fidel Henríquez, consideró como válidamente presentado el reconocimiento, incluso cuando ya estaba iniciado el proceso, y rechazó la demanda de reclamación por considerar que ya tenía constituida la filiación, descartando así la tesis de que la inscripción deba hacerse previo al proceso so pena de no tener ningún valor. (caso "Zappettini con Medina", RDJ., tomo 98 (2001), II; sección 2a, pp. 39 y ss. (La última reforma juntó ambos procedimientos). 
a través del funcionamiento de la voluntad. La consecuencia de dejarlo sin valor, es que por operación del mecanismo legal se afecta a la filiación constituida.

II. Respecto de la acción de impugnación del estado filial, no se trata aquí de un medio para impugnar el reconocimiento, sino que permaneciendo el acto, se ataca el régimen atribuido al acto, en concordancia con la separación entre estado filial y factor de determinación.

La acción de impugnación, en general, se refiere al derecho y a la pretensión que tiene por objeto destruir el estado filial o, lo que es lo mismo, la filiación jurídica. El aspecto específicamente constitutivo de esta clase de sentencia que acoge la pretensión, radica en el cambio jurídico consistente en la extinción del estado filial de paternidad, maternidad o de hijo, previo a aquella y que deja a una persona sin filiación jurídica, de acuerdo al art. 211, lo que la diferencia de la acción de nulidad, que procesalmente no está dirigida a destruir el vínculo filial, sino el acto de reconocimiento; este tipo de sentencia también es constitutiva, pero directamente respecto del acto jurídico.

En cuanto a la causa general para la impugnación, la pretensión se logra a través de la vía del criterio-base y objetando la operatividad del factor sea cual sea este. Lo que se cuestiona es alguna deficiencia en el procedimiento de acceso a la filiación, específicamente, a que el factor de determinación no operó de forma correcta en cuanto a que amparó a quien no correspondía en relación con el criterio-base para dar origen a la filiación. El examen es relativo a la falta de coincidencia entre lo que da cuenta factor de determinación filial, como la sentencia o las presunciones, y la realidad filial biológica. Y todo ello es con independencia de la voluntad que haya tenido el sujeto del reconociente.

Asimismo, debe tenerse presente que el reconocimiento se trata de un factor de determinación, por lo que satisfaciendo los requisitos de formación de la voluntad, teniendo una motivación lícita, cumpliendo con todas las formas y teniendo un objeto adecuado a Derecho, el acto queda perfecto sin vicios. Distinto es que el acto no se corresponda con la realidad, ya que la ley no le exige, a quien lo realice, el tener certeza necesaria de la verdad de su declaración. Dicha exigencia iría en contra de la finalidad expeditiva del reconocimiento, forzando a cualquiera que pretenda reconocer efectuarse pericias biológicas para tener fuertes elementos de contrastación de su hipótesis de ser padre de alguien. Por ende, el hecho de que el factor reconocimiento no dé cuenta de la realidad biológico-filial, no lo hace nulo o inadmisible por ilegal. Tan solo debe ser desplazado su funcionamiento, mediante la parte declarativa de mera certeza de la sentencia de impugnación, que constate que el reconocimiento en verdad no dio cuenta de lo que tenía que dar cuenta: de la procreación, para que así la parte constitutiva de la misma, basada en lo anterior, extinga la relación filial ${ }^{100}$.

${ }^{100}$ En la antigua institucionalidad filial española, Albaladejo sostenía, y era refrendado por Díez-Picazo, que la acción de impugnación tendía a demostrar que el acto era inválido ab initio (DíEz-PICAZo (1973) p. 141). 
Consecuencia de lo anterior es que, si se acepta que el padre que reconoce no puede impugnar, entonces solo le quedará la acción de nulidad para dirigirse en contra del reconocimiento, y del estado filial. Con ello deberá tenerse muy presente que la acción de nulidad presenta unos plazos extremadamente cortos para los casos más factibles de vicio de la voluntad: 1 año plazo (art. 202). De tal manera, el planteamiento de la demanda debe ser cuidadoso, ya que se puede pretender anular mediante el ejercicio de una acción que no corresponda, y que el juez no deberá dar lugar.

Además, en materia de casación, no se puede pretender impugnar el reconocimiento en un recurso de casación, cuando lo que se ejerció fue una acción de impugnación del estado filial. En un recurso de casación se señaló por el recurrente que sostener la irrevocabilidad del reconocimiento es un error de Derecho, ya que en conformidad con los artículos 195 y 211 del Código Civil, este acto puede atacarse mediante la acción de impugnación. La Corte Suprema dictaminó enfáticamente: "Que el recurso de casación en estudio, se desarrolla sobre la base de un argumento erróneo, cual es que el acto de reconocimiento de la filiación puede impugnarse [mediante la 'acción de impugnación']. Sin embargo este derecho, que consagra el artículo 195 del Código Civil, lo es, sin perjuicio de la irrevocabilidad a que se refiere el artículo 184 inciso segundo en relación con los artículos 12 y 189 del citado cuerpo legal; por ende el recurso de casación en estudio adolece de manifiesta falta de fundamento" 101 .

\section{BIBLIOGRAFÍA CITADA}

AbeliuK, René (2000): La Filiación y sus Efectos (Santiago, Edit. Jurídica de Chile, tomo I).

Aguiló, Josep (2000): Teoría General de las Fuentes del Derecho (y del Orden Jurídico) (Barcelona, Ariel) 217 pp.

Alchourrón, Carlos y Bulygin, Eugenio (2000): "Norma Jurídica", en: Garzón, E. y LAPORTA, F. (comps.), El Derecho y la Justicia (Madrid, Trotta).

Atienza, Manuel y Ruiz Manero, Juan (1996): Las Piezas del Derecho (Barcelona, Ariel) $207 \mathrm{pp}$.

Austin, J.L. (2006): "Locuciones Ejecutivas", en: M. SCARIKA y S. TOlEDO (traducc.) Revista Observaciones Filosóficas, disponible: http://www.observacionesfilosoficas.net/ locucionesejecutivas.htlm

Austin, J.L (1990) Cómo Hacer Cosas con Palabras (traducc. G. Carrió y E. Rabossi, Buenos Aires, Paidós) 224 pp.

Bulygin, Eugenio (2001): "Creación y Aplicación del Derecho", Anuario de Filosofía Jurídica y Social (19): pp. 427-446.

Cicu, Antonio (1947): El Derecho de Familia (traducc. S. Sentís, Buenos Aires, EDIAR) 532 pp.

${ }^{101}$ Caso "Vásquez Vargas con Vásquez Alcayaga", sentencia de 30 de octubre de 2003, en www.lexisnexis.cl $\left(n^{\circ}\right.$ identificador 28789). 
CoIng, Helmut (1996): Derecho Privado Europeo (traducc. A. PÉREZ, Madrid, Fondo Cultural del Notariado, tomo I).

CORRAL, Hernán (1999): "Determinación de la Filiación y Acciones de Estado en la Reforma de la Ley n 19.585, 1998”, Revista de Derecho, UCV (20): pp. 39-110.

Chiovenda, Giuseppe (1925): Principios de Derecho Procesal Civil (traducc. J. CASÁIS y SANTALÓ, Madrid, Reus, tomo II) .

DAVIDSON, Donald (1982): "Paradoxes of Irrationality", Philosophical Essays on Freud, Wolheim y Hopkins (eds.), Cambridge University Press, Londres.

Domínguez Águila, Ramón (1977): Teoría General del Negocio Jurídico (Santiago, Editorial Jurídica de Chile) 284 pp.

Domínguez Benavente, Ramón (1969): “La Máxima 'Nemo Auditur...' en la Jurisprudencia Chilena", en: Estudios de Derecho Civil en Honor del Profesor Castán Tobeñas (Pamplona, EUNSA, tomo I).

DíEZ-PICAZO, Luis (1973): Estudios sobre la Jurisprudencia Civil (Madrid, Tecnos, vol. III)

Díez-Picazo, Luis y Gullón, Antonio (1992): Sistema de Derecho Civil (Madrid, Tecnos vol. IV, 6a edición).

Dworkin, R.M (1989): Los Derechos en Serio (traducc. M. GuASTAVinO, Barcelona, Ariel) $508 \mathrm{pp}$.

Flume, Werner (1998): El Negocio Jurídico (traducc. J.M. MiQuel y E. GÓMEZ, Madrid, Fondo Cultural del Notariado) 1082 pp.

Fueyo, Fernando (1959): Derecho Civil. Derecho de Familia (Valparaíso, Imp. y Lito. Universo S.A., tomo IV, vol. III).

Fueyo, Fernando (1982): Teoría General de los Registros (Buenos, Aires Astrea) 248 pp.

Galgano, Francesco (1992): El Negocio Jurídico (traducc. F. Blasco GASTÓ y L. PRATS, Valencia, Tirant lo Blanch) 569 pp.

Gandulfo R., Eduardo (2002): "La Validez en los Contextos de Fundamentación y Aplicación”, Revista de Ciencias Sociales: John Rawls. Estudios en su Memoria (47).

Gandulfo R., Eduardo (2005a): "La Aplicación del Principio 'Venire contra Factum Proprium Non Valet'. Un Caso de Vulgarismo Jurídico”, Revista Chilena de Derecho vol. 32 (2): pp. 363-374.

GANDUlFo R., Eduardo (2005b): "Nueva Reforma a la Filiación: ¿El Hijo Tiene Derecho a una Madre o Padre Cualquiera?", La Semana Jurídica (248); también en www.lexisnexis.cl

GANDUlFo R., Eduardo (2006): “La Filiación, el Nuevo Ordenamiento y los Criterios para Darle Origen, Factores de Determinación y Metacriterios de Decisión”, Gaceta Jurídica (314), también en www.lexisnexis.cl

Homero (2000): Odisea (traducc. J.M. PABON, Barcelona, Gredos).

KraWietz, Werner (1988): "El Concepto Sociológico del Derecho", Doxa (5), traducc. E. GARZÓN VALDÉS: pp. 253-274.

LeÓn Hurtado, Avelino (1991): La Voluntad y la Capacidad en los Actos Jurídicos (Santiago, Editorial Jurídica de Chile, 4a edición) 460 pp. 
Liebman, Enrico (1946): Eficacia y Autoridad de la Sentencia (traducc. S. SENTís, Buenos Aires, EDIAR) $344 \mathrm{pp}$.

Liebman, Enrico (1980): Manual de Derecho Procesal Civil (traducc. S. SEnTís, Buenos Aires, EJEA).

MÉndez Costa, María Josefa et al (1984): Derecho de Familia (Santa Fe, RubinzalCulzoni Editores, tomo II).

NiÑo TejedA, Eduardo (1991/1992): “La Simulación”, Revista de Derecho, UCV (14): pp. 71-96.

Peña Bernaldo de Quirós, Manuel (1989): Derecho de Familia (Madrid, Universidad Complutense de Madrid) 645 pp.

Planiol, Marcel y Ripert, George (SAVATIER R.) (1927): Tratado Práctico de Derecho Civil Francés (traducc. M. DÍAZ, La Habana, Cultural, vol. I) 755 pp.

Rivero HernándeZ, Francisco (1997): Elementos de Derecho Civil (Barcelona J.M. Bosch, tomo IV, 4a edición)

Ramos, René (2001): Derecho de Familia (Santiago, Editorial Jurídica de Chile, tomo II, $3^{\text {a }}$ edición)

RAWLS, John (1995): "Prioridad de lo Justo e Ideas del Bien”, en: Liberalismo Político (traducc. S. MADERO, México DF, FCE).

Ross, Alf (1974): "Auge y Decadencia de las Expresiones Realizativas" Boletín Mexicano de Derecho Comparado (21).

SAlinas A., Carlos et al. (2006): "Matrimonio Civil y Matrimonio Religioso", en: Vidal Olivares, Álvaro (coordinador) Nuevo Derecho del Matrimonio (Santiago, Ediorial Jurídica de Chile).

Salvador, P., Azagra A. y Fernández A. (2004): “Autonomía Privada, Fraude a la Ley e Interpretación de los Negocios Jurídicos”, InDret (3), www.indret.com.

Somarriva, Manuel (1955): La Evolución del Código Civil Chileno (Santiago, Nascimento) 564 pp.

STITCHKIn, David (1965): El Mandato Civil (Santiago, Edit. Jurídica de Chile) 652 pp.

Summers, Robert (2001): La Naturaleza Formal del Derecho (traducc. P. LARRAÑAGA, México DF, Fontanamara) 173 pp.

Veloso, Paulina y SCHMidT, Claudia (2001): La Filiación en el Nuevo Derecho de Familia (Santiago, ConoSur) 454 pp.

VON TuHr, Andreas (1934): Tratado de las Obligaciones (traducc. W. Roces, Madrid, Reus, tomo I).

\section{SENTENCIAS CiTADAS}

Corte Suprema: Sentencia de 19 de diciembre de 1939, RDJ., tomo 37 (1939).

Sentencia de 16 de septiembre de 1942, RDJ., tomo 40 (1942).

Sentencia 19 de mayo de 1958, RDJ., tomo 55 (1958).

Sentencia de 3 de octubre del 2002, rol 2.646-02, en www.lexisnexis.cl ( $\mathrm{n}^{\circ}$ identificador 26031). 
Sentencia de 3 de abril del 2003, rol 2.903-03, en www.lexisnexis.cl (no identificador 26345).

Sentencia de 30 de octubre del 2003, rol 1.994-03 en www.lexisnexis.cl ( $\mathrm{n}^{\circ}$ identificador 28789).

Corte de Apelaciones de Concepción: Sentencia de 11 de agosto de 1927, Gaceta de los Tribunales, $1927,2^{\circ}$ semestre.

Sentencia de 30 de abril del 2001, RDJ., tomo 98 (2001).

Corte de Apelaciones de Arica: Sentencia de 28 de abril del 2003, rol 8.819-02, en www.lexisnexis.cl ( ${ }^{\circ}$ identificador 28789). 